vantagens iniciais, dada a excessiva oferta de escravos no território pernambucano (CARVALHO, 2010).

O Brasil - e Pernambuco em particular - apresenta, dentro desse quadro escravagista, uma memória quase nunca registrada de resistência à escravidão que se manifesta concretamente através dos variados modelos de organização social e espacial e estratégias diversas encontradas pelos cativos em vários períodos onde se fez presente a escravidão no país.

Nunca faltaramfugasem Recifee demais localidades pernambucanas. Sem partir para uma revolta aberta os escravizados encontraram fórmulas de oposição ao cativeiro em alternativas sociais (sendo o quilombo a forma opositiva mais radical) que pouco a pouco despertavam a construção de uma consciência negra baseada na solidariedade e, por que não dizer, na sobrevivência. A fuga era uma decisão extrema dada a hostilidade das alternativas na época. Ela envolvia riscos que iam desde a perseguição e captura pelos capitães de mato até a incerteza do destino nessa comunidade alternativa a qual o fugitivo passaria a pertencer: o quilombo. Quando o escravo fugia, amparado pela possibilidade de um conceito vago de liberdade, ele tinha que se reeducar para ela, o que implicava na aprendizagem da resistência, das técnicas de guerrilha e da adaptação a outras regras diferentes das tantas que ele havia experimentado desde sua captura na África, passando pela travessia no Atlântico e pelas mãos dos seus muitos senhores.

O caminho para a liberdade passava, portanto, por uma conquista principal: a recuperação de sua humanidade natural através do estabelecimento de laços de pertencimento. Sua luta posterior pelo direito ao trabalho e pela conquista gradual de participação dentro do sistema passou, em seu início, pela etapa da busca de um espaço próprio, novo, e pela sua integração a ele.

Os processos de ocupação territorial por quilombos em Pernambuco se relacionam com o contexto sócio-político do período no qual teve início cada uma das comunidades quilombolas. As mais antigas originaram-se quase sempre de fugas de escravos provenientes de fazendas locais e mesmo de locais mais distantes. Em sua maior parte, elas ocupavam terras que não interessavam aos fazendeiros seus contemporâneos. Eram terras sem dono, terras de ninguém. Posteriormente, já no final do século:

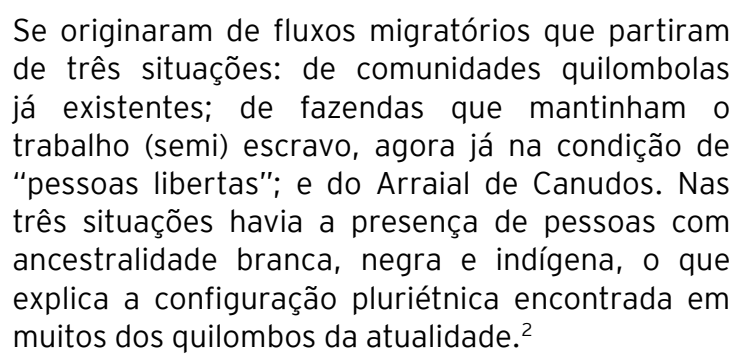

Muitas das pessoas que migravam haviam acumulado algum dinheiro proveniente do trabalho nas fazendas que elas investiram na compra ou arrendamento de terras onde trabalharam na produção agrícola. É nesse contexto que surgem novas comunidades que, nesse deslocamento, às vezes estabeleciam relações de sociabilidade com os indígenas locais. É nesse contexto também, que surgiu a comunidade quilombola Conceição das Crioulas, suporte e meio da arte relacional praticada pelo Movimento Intercultural IDENTIDADES, objeto principal do nosso texto.

\section{O papel da mulher na sociedade patriarcal e escravocrata brasileira}

Dentro da pirâmide social estruturada na sociedade escravocrata brasileira os brancos ficavam no topo, distribuídos em posições melhores em relação ao alto desta por meio do seu poder aquisitivo. Em um degrau abaixo estavam as mulheres, brancas que eram, apesar de brancas, cidadãs de segunda categoria. Em baixo desta construção social ficavam os negros e os indígenas considerados inferiores. Em um nível mais inferior ainda estavam as mulheres negras escravas tanto por serem mulheres, como por serem negras e escravas. Ser mulher, e ser escrava dentro de uma sociedade opressora e sexista, significava ser vulnerável à exploração econômica, sexual e alvo de injustiças e humilhações por parte das demais camadas sociais. A escrava sofria o assédio, o estupro e a opressão generalizada por parte do senhor e não escapava dos ciúmes da sinhá que se vingava como podia e sempre na mulher.

Por outro lado, as mulheres escravas constituíam a maioria dos libertos e, embora reste sempre a ideia de que, generosamente, o senhor de escravos libertasse a escrava como uma espécie de recompensa pela submissão sexual, alguns historiadores se posicionam no sentido de que foram elas que conquistaram essa alforria 
(CARVALHO, 2010, p.222). Uma liberdade que era mais facilmente aceita pelos donos do poder por questões de gênero uma vez que o fato de ser mulher tornava o caminho para a verdadeira liberdade bem mais difícil e então a alforria fornecia uma liberdade "de direito", mas não "de fato". Essa liberdade concedida não assegurava possibilidades econômicas de mantê-la, nem a incluía em um grupo de pertencimento. As mulheres, portanto, tinham um caminho bem mais árduo em direção à liberdade, mesmo quando alforriadas.

E era um caminhar extremamente difícil não só para as mulheres negras, embora a estas coubesse o ônus maior. Afinal, brancas, negras ou mulatas estamos tratando aqui de corpos - marionetes. Um corpo sobre o qual: "as relações de poder têm alcance imediato sobre ele; elas o investem, o marcam, o dirigem, o supliciam, sujeitam-no a trabalhos, obrigam-no a cerimônias, exigemIhe sinais" (FOUCAULT, 1989, p. 28). Esse poder afirmou-se no Brasil patriarcal e escravocrata tanto sobre a mulher branca quanto sobre a negra. Sobre a situação da sinhá branca da casa grande assim se manifesta Gilberto Freyre (apud QUINTAS, 2008, p. 52):

Da mulher-esposa, quando vivo ou ativo o marido, não se queria ouvir a voz na sala, entre conversas de homem, a não ser pedindo vestido novo, cantando modinha, rezando pelos homens; quase nunca aconselhando ou sugerindo o que quer que fosse de menos doméstico, de menos gracioso, de menos gentil; quase nunca metendo-se em assuntos de homem.

$\mathrm{Na}$ esteira das dificuldades rumo à liberdade, coube a ambas, branca e negra, o ônus de sua liberdade gradativa. Mecanismos de sobrevivência pressionaram a busca de alternativas. Depois da abertura dos portos em 1808, de acordo com Marcos J. M. de Carvalho (2010, p. 77):

Muitas mulheres que tentavam fazer valer suas vontades, enfrentando as duras regras não escritas do patriarcado preferiram morar na cidade. Lá havia mais oportunidades e alternativas para se ganhar a vida, principalmente para as mais decididas, tendo ou não filhos.

Os núcleos urbanos existentes ofereciam oportunidades de emprego para mulheres livres no serviço doméstico tradicionalmente destinado às mais pobres onde se incluía a negra liberta. A alternativa para as alfabetizadas e brancas era a função de professora das primeiras letras, piano ou línguas estrangeiras às crianças de famílias mais abastadas. Cabia, porém ao negro, mulher ou homem, o ônus de provar, em um espaço social onde a recaptura era tolerada e pouco investigada pelas autoridades; onde era necessário defender todo o tempo a liberdade conquistada, que ele era legalmente e realmente livre. A cor da pele era, em si, um entrave à liberdade "de fato". Presumia-se a condição de escravo para uma pessoa de cor e a circulação urbana tornava-se perigosa. Em tal situação, a conquista de um espaço econômicosocial para viver tornava-se uma questão de sobrevivência e não é de se estranhar que esse espaço devesse ser o mais isolado possível da comunidade branca.

Um exemplo coletivo dessa busca por um espaço é a comunidade quilombola Conceição das Crioulas abrigada no sertão de Pernambuco. Sua história, baseada em uma narrativa oral, remete às suas mulheres fundadoras. Trata-se de um quilombo fundado por mulheres e onde, até hoje, são elas as protagonistas das lutas e conquistas do grupo de pertencimento por elas criado. Os padrões discriminatórios em relação às mulheres nas tantas sociedades, cronologicamente e espacialmente diversificadas, parecem nesse espaço social ali construído terem se erradicado ou pelo menos amenizado. Naquele espaço, as mulheres se organizaram na construção de uma nova sociedade utilizando-se dos instrumentos possíveis para a desconstrução de ideias e atitudes que viessem a negar seus direitos dentro do quadro maior dos próprios direitos humanos.

\section{Sobre a comunidade quilombola Conceição das Crioulas: um conceito de nação conjugado no feminino?}

Localizada no município de Salgueiro, Pernambuco, Conceição das Crioulas tem uma história oral que remete à luta de seis negras livres que chegaram à região, arrendaram uma área e, graças ao cultivo, fiação e venda do algodão (que era comercializado na cidade de Flores), conseguiram arrendar três léguas de terra. Gleba esta que depois compraram e escrituraram em um cartório de uma localidade próxima denominada Torre, em 1802, por um escrivão de nome Pedro José Delgado. Essa tradição oral de cunho quase mitológico estabelece a forma de ocupação da terra pela comunidade no início do século XIX. 
Os três mil quinhentos e cinquenta e dois habitantes atuais do distrito ocupam uma área de 16.885,0678 hectares no povoamento central. A maioria dos habitantes habita os "sítios" que se espalham no território comum ${ }^{3}$. Esta comunidade quilombola faz parte das muitas já reconhecidas pelo Estado Brasileiro por meio de "certificação feita pela Fundação Cultural Palmares (FCP) (certificação do autorreconhecimento) e da abertura de processo de regularização dos territórios quilombolas pelo Instituto Nacional de Colonização e Reforma Agrária (INCRA)"'4. Conceição das Crioulas, juntamente com outras comunidades semelhantes espalhadas pelo território brasileiro formam grupos de resistência negra à escravidão inicial e à exploração de mão de obra posterior.

No início do século $X X$, as terras adquiridas diminuíram de extensão em virtude de invasões e aquisições ilícitas por parte de fazendeiros. 0 território foi encolhendo e só em 2014 a posse da terra foi legitimada pelo governo federal e os fazendeiros invasores intimados a abandonar a terra. O dia vinte e dois de setembro daquele ano passou a ser um dia histórico para a comunidade. Naquela data, foram entregues pelo INCRA três títulos de domínio de cinco imóveis rurais que estavam dentro do Território Quilombola. Dessa maneira, aproximadamente 898 hectares passaram a compor efetivamente o patrimônio coletivo da comunidade, beneficiando 750 famílias. A titulação ocorreu mediante a outorga de título coletivo e pró-indiviso à comunidade, em nome da Associação Quilombola de Conceição das Crioulas (AQCC) ${ }^{5}$.

As mulheres e suas ações têm forte significação dentro desta comunidade desde a sua fundação, passando pela resistência à expropriação da terra, à transmissão de sua cultura. Essa resistência está intimamente ligada à formação das lideranças que compõem a estrutura política em Conceição das Crioulas, lideranças que se conjugam no feminino tanto no que diz respeito às referências históricas quanto às do dia a dia comunitário. Apesar do empenho atual de alguns homens no sentido de participação nas lutas pelos direitos quilombolas ainda predomina maciçamente a presença da mulher, guerreira e educadora, nas decisões comunitárias:

O papel da mulher é assegurado na descendência.

É "nelas que tudo começa": a fundação da comunidade (incluindo a compra da terra), a origem do nome, a defesa do território frente às "invasões" das quais resultaram expropriações; elas também estão presentes na execução e perpetuação de determinadas práticas ou atividades culturais como os ofícios de benzedeira e parteira e na produção de trabalhos artesanais. As mulheres que se dedicam a essas atividades dizem ter aprendido com suas mães ou avós. (LEITE, 2010)

A batalha prossegue. As mulheres de Conceição das Crioulas se transformaram, romperam com a tradição secular de subserviência. Suas conquistas as afastaram da condição de mero celeiro de mão de obra das cidades vizinhas. A negritude hoje não é mais motivo de vergonha, mas de orgulho e a educação é o instrumento de conquista na luta pelos seus direitos. Nas palavras de Maria Diva da Silva Rodrigues:

As escolas ensinavam para a gente, de forma bem sutil, que era feio ser negro, que nosso cabelo por ser pixaim era feio. Então era pra se dizer que era moreno, moreno escuro, moreno claro. Negar que era de Conceição porque ser de Conceição era ruim, porque era um lugar atrasado onde só tinha negro e negro não era uma coisa boa. (Maria Diva da Silva Rodrigues, In CARRION, 2013, p. 54)

Elas interromperam com esse discurso. E propuseram para as escolas um currículo alternativo no qual os valores ancestrais fossem contemplados e que contribuísse para semear o orgulho no lugar da vergonha das suas origens. Hoje, Gilvania, Aparecida Mendes, Márcia Jucilene, Maria Diva e Valdeci entre tantas outras são mulheres que sabem os caminhos que devem ser percorridos. São os pilares atuais da comunidade. Abrem caminhos, Rotas diversas das de suas antepassadas fundadoras, mas não menos importantes. Elas objetivam novas formas de liberdade e a identidade como princípios norteadores. A liberdade física, meta das antigas escravas, transformou-se na luta política pela cidadania em toda a sua plenitude.

A experiência educacional de Conceição das Crioulas é considerada referência para o movimento quilombola e outras organizações que trabalham com educação. Seu projeto é diferenciado e trabalha com uma concepção e práxis na qual os valores, a cultura, os costumes, as tradições, a sabedoria das pessoas mais velhas e a história dos antepassados fazem parte do processo educativo.

A presença e a consciência do papel da mulher nas 
conquistas da comunidade são marcos a serem observados em um espaço social que poderia englobar um conceito de nação. Uma nação, em seu sentido político moderno: uma comunidade de indivíduos vinculados social e economicamente geralmente de um mesmo grupo étnico, que compartilham certo território, que reconhecem a existência de um passado comum, que têm uma visão de futuro em comum e que acreditam que esse futuro será melhor se se mantiverem unidos do que separados. A partir dessa premissa, Conceição das Crioulas é uma nação. Uma nação onde os padrões sociais e culturais discriminatórios com relação às mulheres presentes em maior ou menor grau em todas as regiões do planeta parecem não mais existir. Nela, as mulheres que se destacaram na luta pela aquisição, construção e recuperação das terras que ocupam e que hoje lutam pela construção de uma identidade étnica estão no comando.

A abertura dessas mulheres para novos horizontes passa por uma emancipação pela educação. A consciência sobre este instrumento libertador está presente nas palavras de sua principal líder política Gilvania Maria Silva quando fala sobre sua comunidade:

mergulhada numa busca constante de ações direcionadas à educação, à saúde e ao reconhecimento da sua cultura, do processo da reconstrução da identidade e de seu território. Mesmo diante do cenário de dúvidas, a educação era entendida pelos seus moradores (as) como atividade importante. (SILVA, 2013, p. 47)

É nessa conjuntura, a partir dessa proposta, que prioriza a educação como veículo de emancipação, que a arte relacional ou contextual praticada pelo Movimento Intercultural IDENTIDADES, no qual o artista, participante da história imediata, encontra seu espaço na comunidade. Esse engajamento, essa forma de criar artístico, não visa o sublime ou o transcendente; sua proposta se volta para a possibilidade de transformação do social e nele encontra seus instrumentos. A arte, devemos lembrar, pode ser o último reservatório do imaginário a escapar de ser incorporado/ apropriado pelo sistema que hoje serve ao capitalismo neoliberal e o seu consumir ideológico. As práticas artísticas que envolvem a política relacional podem abrigar um sonho para além das servidões e ser uma promessa de reconciliação com o humano em sua expressão maior. A colaboração com a comunidade através da arte-educação é o objetivo do movimento.

\section{Sobre o Movimento Cultural IDENTIDADES}

A história da relação entre arte e política aparece sempre ao longo da história da arte. Ela, a arte, serviu a religiões ou estados, passando sua mensagem em incontáveis situações no tempo e no espaço. O artista pode abrir caminhos, resistindo e isolando-se do ruído circundante e gerar novas propostas e ressonâncias.

A arte é aquilo que resiste, segundo Deleuze (1999). Para Jacques Rancière (2009, p.26), ela é um agente transformador pela sua capacidade de reconfigurar o sensível e é a partir "do recorte sensível do comum, da comunidade, das formas de sua visibilidade e de sua disposição, que se coloca a questão da relação estética/politica". Esse olhar priorizaria a noção de envolvimento em relação ao desenvolvimento (idem).

Para Nicolas Bourriaud (2009, p.31), cabe ao artista a tarefa de "devolver concretude ao que se furta à nossa vida" o que ele faria rompendo com a lógica da sociedade do espetáculo, com a escala diluidora da globalização e tentando reconstruir e restituir fé a um mundo cuja dominação cultural pelo capitalismo avançado conduz a um cotidiano transformado em um produto de consumo. Para ele, a possibilidade desta arte relacional "uma arte que toma como horizonte teórico a esfera das relações humanas e seu contexto social" (ibidem, p. 19) atende aos objetivos estéticos, culturais e políticos postulados pela contemporaneidade e estaria contribuindo para a preparação de um mundo futuro. Pressente-se já, através do seu pensamento, a necessidade de retomada de uma política ligada a uma transformação estética, ou, como quer Carlos Vidal (1997, p 22) “uma refundação da linguagem estética que ultrapasse a fatalidade do triunfo da industrialização do pensamento".

A arte contemporânea desenvolveria, portanto, um projeto político quando se empenha, por exemplo, em investir e problematizar as esferas das relações humanas. Essa condição corresponde, hoje, à iniciativa de artistas que mergulham no campo ampliado da criatividade, no qual o caráter político é relacionado ao fato de uma integração do trabalho artístico com a vida. O trabalho da arte, nas suas novas formas, ultrapassa a antiga produção de 
objetos destinados a serem vistos e consumidos e investe em novos horizontes que funcionam ora como mapas que orientam seu movimento, ora como motor de um desejo de caminhar novamente em busca de um ideal. A liberdade conceitual, imaginativa e perceptiva das práticas artísticas que envolvem a política pode abrigar um sonho para além das servidões e uma promessa de reconciliação com o humano em sua expressão maior. Sua proposta encontra-se para além das múltiplas grades com as quais o capital burocratiza e regula a arte incidindo em sua produção.

Para a concretização desta possibilidade, desta nova práxis, o envolvimento do artista, segundo José Carlos de Paiva (2009, p. 53), deve procurar modelos que ultrapassem as fragilidades e invistam nas possibilidades utópicas do mundo contemporâneo, "em contextos sociais precisos, onde se promoveu uma aproximação epidérmica". Tomando-se o cotidiano como base, "pode-se criar diferentes versões da realidade", afirma Bourriaud (2009, p.83). Nestas condições, a arte se apresentaria "como uma mesa de montagem alternativa que perturba, reorganiza ou insere as formas sociais" (idem). Caberia ao artista desprogramar a realidade para reprogramar uma estética que se pautaria em função das relações inter-humanas. Uma estética que contemple o "outro", legitimando-o. O mundo da arte e da vida estaria, então, de fato, cada vez mais fundido e a estética, como ciência do sensível, em consonância com esse novo olhar.

Conduzidos pelos artistas, os indivíduos seriam impulsionados a lutar por um ser melhor, um ser que se interessaria pelos outros, um ser coletivo, um ser político. Essas reivindicações se concretizariam a partir de uma transformação radical que englobaria a própria maneira de conceber a arte.

É trabalhando neste intervalo micropolítico, que o movimento intercultural IDENTIDADES, nascido em Porto, Portugal, se manifesta. Trata-se de um movimento artístico, atuante desde os anos 90, mais precisamente concebido em 1996, que participa dos conflitos da era pós-colonial tendo como objetivo as relações culturais diretas em vários espaços geográficos do planeta de histórico colonial português.

Atuando em comunidades situadas em três espaços geograficamente distintos e com características específicas, o movimento mobiliza artistas, professores e estudantes de arte que, fora do seu espaço de conforto buscam, através da reflexão partilhada, interagir nestes três espaços sociais. A partir de Porto, como já foi dito anteriormente, ele se relaciona com espaços de colonização lusa: Moçambique, Cabo Verde e Conceição das Crioulas, comunidade quilombola no Nordeste do Brasil.

O movimento intercultural IDENTIDADES é constituído por indivíduos que se congregam em um grupo não homogêneo tanto no que diz respeito a objetivos pessoais quanto no que diz respeito à forma de criação e expressão. Eles têm em comum o interesse pelo resgate de um perfil de identidade cultural fragmentado, destruído ou em processo de destruição, procurando um sentido para a ação artística, estabelecendo vínculos relacionais adequados aos interesses das comunidades em que atuam.

É nesse terreno intercultural "onde a história confere posturas próprias e um tempo particular perante o contemporâneo", segundo José Carlos Paiva (2009, p. 58), que os membros do grupo se assumem enquanto artistas e enquanto cidadãos. As ações artísticas de grupos como o movimento intercultural IDENTIDADES procuram construir e realizar modelos de ação dentro da realidade existente e que tenham como objetivo maior fazer a diferença.

\section{Sobre a ação do Movimento Intercultural IDENTIDADES em Conceição das Crioulas}

De acordo com José Carlos de Paiva (2007, p.18), na arena relacional em que ele próprio se move e onde também transita o movimento IDENTIDADES, "a marca da vida escolar nunca deixa de dominar". O envolvimento do movimento na comunidade quilombola Conceição das Crioulas segue essa proposta e "assume a ação como intervenção política em contextos onde a população se envolve em seu próprio desenvolvimento" (2011, p.31). Em Conceição das Crioulas, a política se faz através da arte-educação.

O envolvimento do movimento com a comunidade iniciou-se em 2003. Sua história, entretanto, remete aos primeiros contatos de José Carlos de Paiva, líder do IDENTIDADES, com a capital do Estado de Pernambuco, Recife, representando 
a GESTO Cooperativa Cultural. O contato se deu através da Fundação Joaquim Nabuco via o seu presidente, Fernando Freire e tinha como objetivo estabelecer um programa de intercâmbio artístico e cultural. Do encontro inicial resultou o projeto "Cumplicidades", que promoveu, entre os anos de 1993 a 1996, dezenas de eventos culturais em Portugal no Nordeste do Brasil (PAIVA, 2009, p.134). Para Paiva, o tempo que transcorreu entre estes primeiros contatos nordestinos, que precederam o que aconteceu com Conceição das Crioulas foi o necessário para proporcionar amadurecimento e, então, através do Centro de Cultura Luiz Freire, em 2003, estabelecer relações com a comunidade.

Em 2003, contato estabelecido, foi criada uma oficina de artes plásticas ministrada por Iva Correia e Monica Farias (de Porto) e uma de teatro que foi dada pelo ator moçambicano Rogério Manjate. Montou-se uma exposição em uma das dependências de uma escola local intitulada "Pano para Mangas" onde o movimento foi apresentado para a comunidade. Deste momento fala Monica Faria, integrante do IDENTIDADES:

\begin{abstract}
Eu, a Iva Correia, ambas viajando do Porto, e o Rogério Manjate de Moçambique tivemos a oportunidade de visitar e conhecer a comunidade através do 'movimento intercultural Identidades', a convite do Centro de Cultura Luís Freire (CCLF) e da Associação Quilombola da Conceição da Crioulas (AQCC) para realizar uma oficina de artes plásticas, principalmente para a faixa etária infantil e juvenil. O Rogério Manjate orientou uma oficina de teatro. A data escolhida foi a grande festa da 'Nossa Senhora da Conceição' a santa padroeira da comunidade, em pleno agosto sertanejo. A festa durou quinze dias e durante esse tempo organizaram-se várias oficinas: teatro, contação de histórias, história da África, artes plásticas, dança e percussão. (FARIA, 2011, p.55)
\end{abstract}

No ano seguinte, 2004, o IDENTIDADES voltou à Conceição das Crioulas para sentir as respostas da comunidade à ação inicial e ao interesse pela construção de uma base na comunidade de caráter mais permanente. A partir de uma troca de ideias com a comunidade e da explicitação das intenções do grupo, foi aprovado um programa intitulado "Deslocações" que se centrava em intervenções através das linguagens do Vídeo, do Webdesign, da Cerâmica, da Educação Visual e da Expressão Plástica. A proposta foi aceita pela comunidade e o grupo retornou em 2005 e, através da preparação de seis jovens da comunidade, durante nove dias, possibilitou-se a criação de um coletivo intitulado "Crioulas Vídeo" que passou a se constituir em mais uma ferramenta na luta pela identidade local através da produção de vídeos que divulgam a sua história e realizações. ${ }^{6}$

O Crioulas Vídeo (fig. 1) formou-se junto aos jovens da comunidade. Entre os membros foram escolhidos inicialmente seis: Marta Adelaide, Aldamir José, Martinho Mendes, Francisco Mendes, Joséane de Oliveira e Reginaldo Antônio. Posteriormente, a eles se juntaram Jocilene e Josicleide. 0 objetivo da equipe é o registro dos acontecimentos da comunidade, ter autonomia para contar sua própria história até então contada por olhares externos. Vários documentários foram produzidos desde sua criação.

Hoje, a ação do IDENTIDADES centra-se principalmente no trabalho desenvolvido com as professoras, para que elas adquiriram as competências necessárias para o ensino da arte na comunidade. O Crioulas Vídeo anda sozinho. A introdução da arte no universo da comunidade, nas palavras de Márcia Jucilene do Nascimento?, professora, transforma Conceição das Crioulas em uma "comunidade mais desenvolvida e politizada" e "ciente dos rumos e passos necessários para se chegar às conquistas importantes". É interessante recordar que, neste espaço social, o conceito erudito ocidental de arte não existe. Seus habitantes se expressam através do artesanato e das artes populares como a dança, a música e a culinária. A arte só é compreendida a partir de seus reflexos práticos sobre a comunidade e de como ela pode servi-la.

Formar professores na área artística poderia contribuir para uma forma mais ampliada de percepção e fruição da arte. Para uma ampliação da sensibilidade dos alunos o que poderia gerar outras percepções e competências sempre tendo em vista, porém, que, para uma comunidade que se propõe a andar sozinha, como é o caso de Conceição das Crioulas, e que anseia por uma educação baseada em currículo diferenciado, tendo como comparação o currículo formal que é visto como sendo externo e global, o ensino da arte deve acompanhar suas particularidades.

O projeto "Expressões Artísticas nas Escolas da Comunidade" (fig. 2) dá continuidade, hoje, às ações do IDENTIDADES em Conceição das Crioulas. 


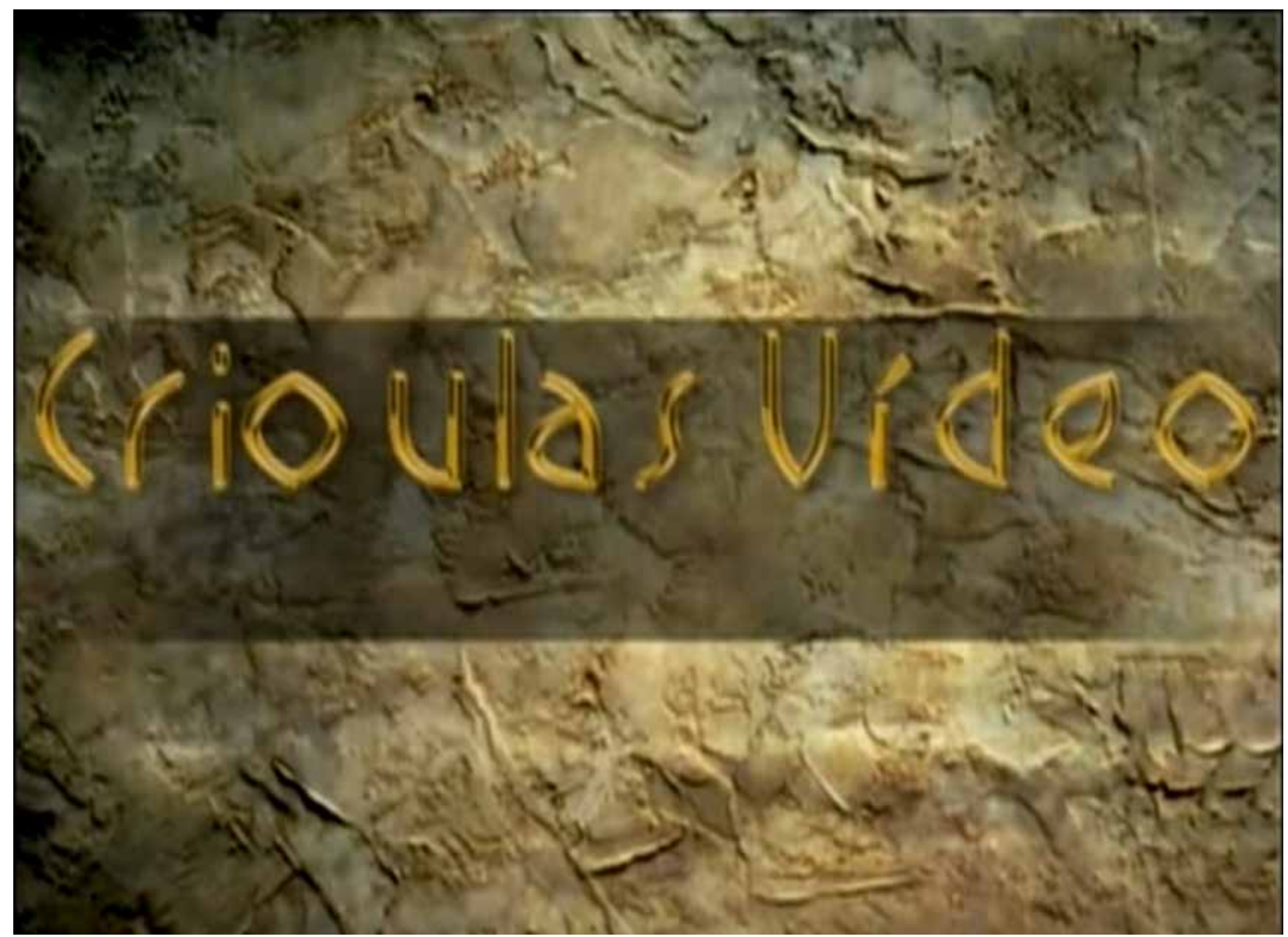

Figura 1 - Crioulas Vídeo. Serra das princesas. Documentário. Disponível em https://youtu.be/OzEfoJXIHNw

Ele visa à construção conjunta de um Currículo nas Artes que contemple a necessidade coletiva e que invista na construção de um professor apto para fazer a ponte entre o senso comum e o conhecimento teórico artístico. Elisabete Mônica Moreira Faria, a já citada participante do movimento e doutoranda em Educação Artística pela Universidade de Porto com tese na qual a pesquisa de campo foi realizada na comunidade, reforça:

A comunidade entendeu que deve integrar as diversas áreas da expressão no seu currículo, num processo de cruzamento intercultural com - IDENTIDADES. Neste contexto o projecto 'Expressões Artísticas nas Escolas da Comunidade' visa elaborar uma discussão construtiva e participativa para um Currículo nas Artes ${ }^{8}$.

Com uma proposta de educação diferenciada, a comunidade quilombola de Conceição das Crioulas pretende encontrar outras modulações para as oposições entre periferia e centro, atrasado e desenvolvido, subalterno e dominante, popular e acadêmico, a partir de relações de reciprocidade e de diálogo. A arte pode ser uma de suas rotas e o Movimento Intercultural IDENTIDADES contribui para que a comunidade a percorra. Marcia Jucilene Nascimento, professora e ativista de Conceição das Crioulas, acredita nisso. Diz ela:

Penso que Arte é o que a gente faz com amor, com dedicação, com cuidado. Ela é intencional, e pode ser representada de diversas formas e em diversos campos: político, social, religioso, cultural etc. O que é mais forte no nosso lugar é a arte de lutar coletivamente pelo bem da comunidade ${ }^{9}$.

\section{NOTAS}

1. CUTI (Luiz Silva). Ferro (In CAMARGO, 1986, p.90).

2. SERTÃO QUILOMBOLA. A formação dos quilombos no sertão pernambucano. Publicação do Centro Cultural Luís Freire. Recife: Centro Cultural Luís Freire: 2008, p.9.

3. Fonte: Relatório da Fundação Cultural 


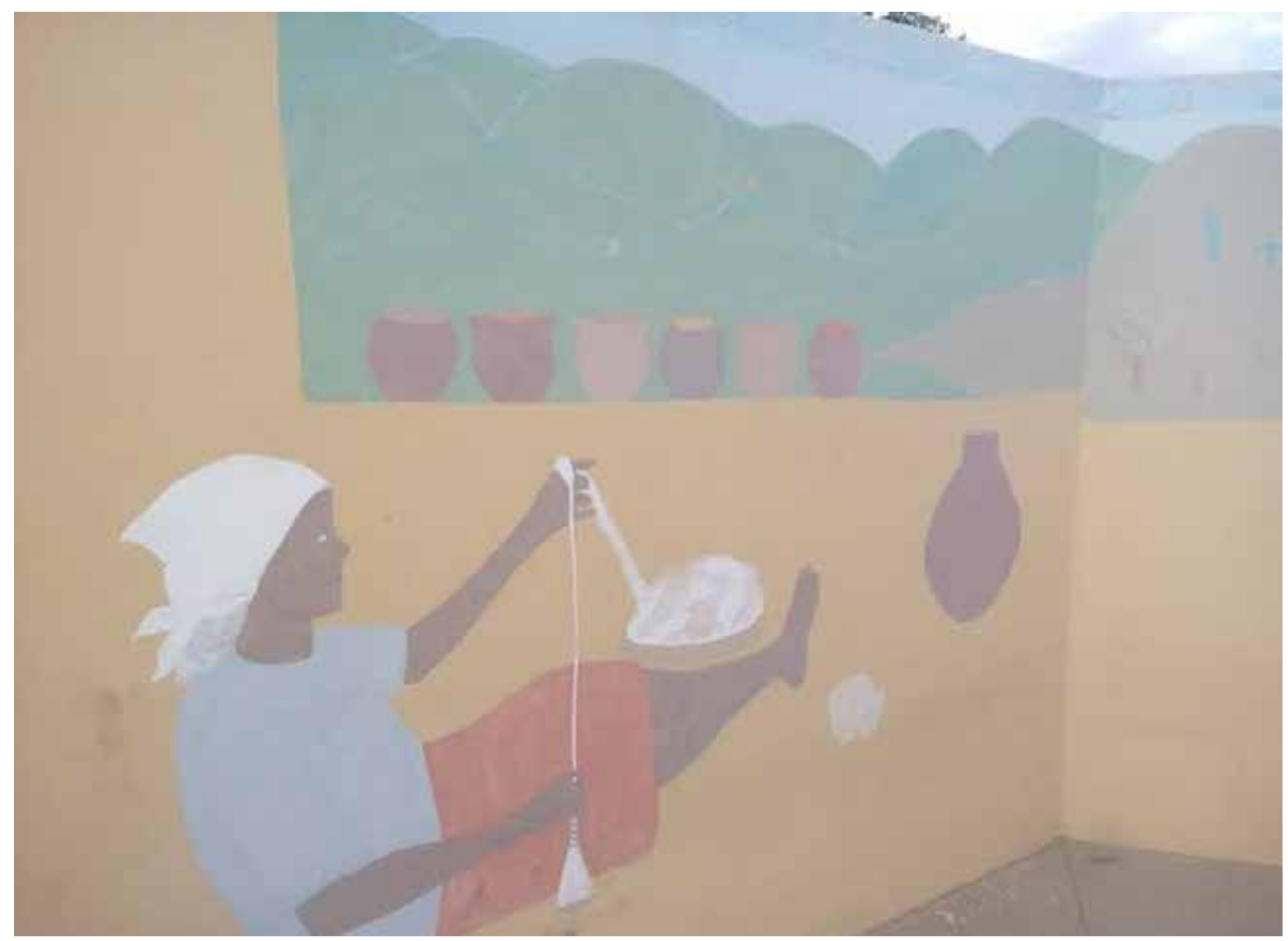

Figura 2 - Mural feito pelos alunos da Escola Quilombola Prof. Rosa Doralina Mendes. Projeto "Expressões Artísticas nas Escolas da Comunidade". Foto Madalena Zaccara, 2015.

Palmares, publicado no Diário Oficial da União, em 11/09/1998 (apud LEITE, 2010).

4. Entende-se por comunidades quilombolas certificadas todas aquelas que manifestaram a afirmação da sua identidade étnica como comunidades remanescentes de quilombos e tiveram seus dados incluídos no cadastro geral junto a FCP conforme o Art. 3) do Decreto 4.887/2003: “§ 4) a autodefinição de que trata o § 1) do art. 2) deste Decreto será inscrita no Cadastro Geral junto à Fundação Cultural Palmares, que expedirá certidão respectiva na forma do regulamento "(apud SILVA, 2013, p. 29).

5. A Associação luta pelo direito da comunidade quilombola de Conceição das Crioulas ao seu território e pela sustentabilidade dessas famílias. Nesse sentido, produzem, de forma sustentável, artesanatos da fibra do caroá, que contam a história e reafirmam a identidade étnica e cultural do povo quilombola, fortalecendo, ainda, a organização política local. Fonte: site da AQCC. Disponível em: http://www.caatingacerrado.com. br/aqcc-associacao-quilombola-de-conceicaodas-crioulas-pe/. Acesso em: 20 ago. 2015.

6. O Crioulas Vídeo é uma equipe de produção de vídeo formada por jovens da comunidade. Para a criação desse grupo foi feita uma escolha entre jovens da comunidade efetuada de forma conjunta. Foram selecionados: Marta Adelaide, Adalmir José, Martinho Mendes, Francisco Mendes, Joséane de Oliveira e Reginaldo António. Hoje, o acervo das Crioulas Vídeo tem vários filmes e seis documentários.

7. Entrevista concedida a Madalena Zaccara, Conceição das Crioulas, mar. 2015.

8. Entrevista concedida a Madalena Zaccara, dez. 2013.

9. Marcia Jucilene Nascimento. Entrevista concedida a Madalena Zaccara, 2015. 


\section{REFERÊNCIAS}

ARARIPE, André; NASCIMENTO Erika (Org.). Sertão Quilombola: a formação dos quilombos no sertão pernambucano. Recife: Publicação do Centro Cultural Luiz Freire. Governo do Estado de Pernambuco, 2008.

BAUMAN, Zygmunt. Em busca da política. Rio de Janeiro: Zahar Editora, 2000.

BOURRIAUD, Nicolas. Pós-produção. Como a arte programa o mundo contemporâneo. São Paulo: Martins Fontes, 2009.

CAMARGO, Oswaldo de (Org.). A razão da chama. Antologia de poetas negros brasileiros. São Paulo: GRD, 1986.

CARRION, Dirce (Coord.). Olhares Cruzados, Brasil Etiópia. Kembata, Conceição das Crioulas. São Paulo: Editora Reflexo, 2013.

CARVALHO, Marcus J. M de. Liberdade, rotinas e rupturas do escravismo no Recife. 18221850. Recife: Editora da Universidade Federal de Pernambuco, 2010.

CRIOULAS VÍDEO. In: ID10: com 10 anos o Identidades esclarece-se e dá-se a conhecer. Porto: Gesto, 2007.

DELEUZE, Gilles. O ato da criação. A obra de arte não é um instrumento de comunicação. Folha de São Paulo, São Paulo 27 de junho de 1999.

FARIA, Monica. Mungunzá ou Cachupa: o direito à conquista e à descoberta de uma nova receita pedagógica. In: PAIVA, José Carlos de; MARTINS, Catarina S. (Org.). Investigar a partir da acçao intercultural. ID -CAI (Coletivo de Ação e Investigação). Porto: Gesto, 2011.

FOUCAULT, Michel. Vigiar e punir: história da violência nas prisões. 7. ed. Petrópolis: Vozes, 1989.

HALL, Stuart. A identidade cultural na pósmodernidade. Rio de Janeiro: DP\&A, 2006.

LEITE, Maria Jorge dos Santos. Conceição das Crioulas: Terra, Mulher e Política. Sankofa. Revista de História da África e de Estudos da Diáspora Africana, ano III, n. 6, dez./2010. Disponível em: file:///C:/Users/mada/Pictures/88789126256-1-SM.pdf. Acesso em: 23 ago. 2015.
PAIVA, José Carlos de. ARTE/desenvolvimento. Tese (Doutorado) - Faculdade de Belas Artes, Universidade do Porto. Porto, 2009.

Entrada de leão, saída de cordeiro. In: ID10: com 10 anos o identidades esclarece-se e dá-se a conhecer. Porto: Gesto, 2007.

No Sertão pernambucano à procura de uma imagem mais nítida do descontentamento como artistas, saboreando mugunzá. In: PAIVA, José Carlos de; MARTINS, Catarina S. (Orgs.). Investigar a partir da acçao intercultural. ID -CAI (Coletivo de Ação e Investigação). Porto: Gesto, 2011.

QUINTAS Fatima. Sexo à moda patriarcal. $O$ feminino e o masculino na obra de Gilberto Freyre. São Paulo: Global, 2008.

RANCIÈRE, Jacques. A partilha do sensível: estética e política. São Paulo: Editora 34, 2009.

SILVA, Gilvania Maria. Meus primeiros passos na busca de pertencer a Conceição das Crioulas. In: CARRION, Dirce (Coord.). Olhares Cruzados, Brasil Etiópia. Kembata, Conceição das Crioulas. São Paulo: Editora Reflexo, 2013.

SOUZA LEAO, Débora de; ALBUQUERQUE, Flávio Rabelo Versiani; VERGOLINO José Raimundo Oliveira. Financiamento e organização do Tráfico de Escravos para Pernambuco no Século XIX. Disponível em: http://www.anpec. org.br/revista/aprovados/Escravos.pdf. Acesso em: 20 ago. 2015.

VIDAL Carlos. Definição da arte política. Lisboa: Fenda, 1997.

ZACCARA, Madalena. Reflexões sobre identidade, periferia e o sistema de internacionalização da arte contemporânea. In: SILVA, Maria Betânia; WILNER, Renata; ZACCARA, Madalena (Org.). Arte Cultura e Memória. Recife: Editora da Universidade Federal de Pernambuco, 2012.

Partidas e Regressos: a atuação do movimento IDENTIDADES no arquipélago de Cabo Verde. ENCONTRO DA ANPAP, 23., 2014. Ecossistemas Artísticos. Anais... Disponível em: http://www.anpap.org.br/anais/2014/ANAIS/ Comit\%C3\%AAs/1\%20CHTCA/Madalena\%20 Zaccara.pdf. 


\section{SOBRE A AUTORA}

Madalena Zaccara possui graduação em Arquitetura e Urbanismo pela Universidade Federal de Pernambuco (UFPE), bacharelado em Direito pela Universidade Católica de Pernambuco (UNICAP), mestrado (DEA) em História e Civilizações - Université Toulouse II, Toulouse, França e doutorado em História da Arte - Université Toulouse II, também em Toulouse, França, como bolsista Capes. Tem pós-doutorado pela Escola de Belas Artes da Universidade de Porto, Portugal, também como bolsista Capes. Atualmente é Professor Associado III da Universidade Federal de Pernambuco. Ensina no Programa Associado de Pós Graduação em Artes Visuais UFPE-UFPB. Lidera o grupo de pesquisa "Arte, Cultura e Memória" que se volta para a pesquisa da História e Teoria das Artes Visuais no Brasil com ênfase para o Nordeste. Atua principalmente nos seguintes temas: História da Arte e Crítica de Arte. É membro da Associação Nacional dos Pesquisadores de Artes Plásticas (ANPAP), da FAEB (Federação dos Arte Educadores Brasileiros) e do Instituto de Investigação em Arte, Design e Sociedade I2ADS (Porto, Portugal). É representante da ANPAP em Pernambuco e membro do Comitê de Teoria, História e Crítica de Arte desta associação. Tem vários livros, capítulos de livros e artigos publicados. Endereço eletrônico: madazaccara@gmail.com. 


\title{
NEM CENTRO, NEM PERIFERIA: SOCIABILIDADE, CULTURA E MUNDOS SONOROS EM BAIRROS POPULARES EM SALVADOR
}

\author{
Angela Lühning
}

\section{Resumo}

Esse artigo aborda as complexas relações entre espaços urbanos socialmente estigmatizados - bairros populares em Salvador -, as redes de sociabilidade de seus moradores, o papel de suas expressões culturais/ musicais e as suas possíveis contribuições para a sociedade brasileira. O ponto de partida é a análise dos conceitos relativos a esses espaços e seus congêneres - no Rio de Janeiro chamados de favelas -, para entender o seu lugar na sociedade brasileira, em busca de uma desconstrução de preconceitos e estigmas a partir do próprio lócus: os bairros populares. Estes são apresentados através de uma densa etnografia etnomusicológica, baseada em anos de observação e vivência da autora em um desses bairros em Salvador com ênfase no universo sonoro/ musical e sua percepção pelos próprios moradores, majoritariamente afro-descendentes. Entre as conclusões ressalta-se a importância do espaço público e a convivência de estilos musicais de forma inter- e intrageracional nestes bairros que se tornaram usinas de criatividade musical, a partir de uma de suas maiores características: estar em processo de constante movimento. Assim os bairros populares/ favelas contribuem para uma possível e necessária reinvenção das cidades brasileiras, também através de suas músicas.

\section{Palavras-chave:}

Bairros Populares, Música e Sociabilidades, Música Urbana, Etnomusicologia.

"As aparências enganam ..."1

\section{Introdução: motivações}

Já se passaram 125 anos desde que Aluísio de Azevedo publicou "O cortiço" e quase 20 anos desde a publicação do romance "Cidade de deus",

\section{Abstract}

This article deals with the complexities of socially stigmatized urban spaces known in Salvador as bairros populares (roughly, "ghettos"), focusing on residents' social networks, local cultural/ musical expressions, and the possible ways in which these contribute to Brazilian society. The point of departure here is an analysis of concepts related to these spaces and their congeners, such as Rio de Janeiro's favelas, not only to understand their place in Brazilian society but also in an effort to deconstruct the prejudices and stigmas surrounding the locus itself: the bairros populares. The author introduces these issues through a thick ethnomusicological ethnography of a bairro popular of Salvador, rooted in many years of observation and experience living in the neighborhood, that emphasizes its sounded/ musical universe as well as the perception of this universe by the neighborhood's residents, the majority of whom are Afro-descendent. The study reveals, among other things, that public space in these neighborhoods is especially important, as it allows the interaction of musical styles in an interand intragenerational way. The process of constant movement that emerges form such musical interactions transforms these neighborhoods into hotbeds of musical creativity. As such, the bairros populares/favelas contribute toward the possible and necessary reinvention of Brazilian cities, also by way of its music.

Keywords:

Bairros Populares (Ghettos), Music and Sociabilities, Urban Music, Ethnomusicology.

ambos retratando a vida em bairros periféricos cariocas a partir das histórias reais (ou quase reais) de pessoas ${ }^{2}$. O romance de Paulo Lins desencadeou, além do filme homônimo, a produção de livros e filmes nacionais sobre temáticas correlatas que, por sua vez, alimentaram o recente movimento de 
turismo para os morros pacificados no Rio. Mas, o assunto não se esgotou ainda: apesar da sua constante inserção nas mídias, a incompreensão dos espaços urbanos chamados de favelas, bairros populares, cortiços, vilas, palafitas e invasões, entre outros, parece continuar, bem como a própria existência desses espaços irreverentes e impertinentes (para muitos), com tendência de crescimento constante ${ }^{3}$.

Este texto aborda esses espaços sociais periféricos, em geral estigmatizados, nos quais pessoas e expressões culturais coabitam, estabelecendo densas inter-relações de sociabilidade. Proponho discutir expressões culturais/musicais e mundos sonoros a partir do local de sua criação, recriação e fruição. As razões são duas: ultimamente tenho presenciado várias apresentações em encontros científicos (ou não) e lido textos sobre estilos musicais oriundos de bairros populares de várias capitais brasileiras como funk, pagode, arrocha e tecnobrega e outros mais, sem que, em geral, fossem mencionados maiores detalhes dos contextos de sociabilidade destes estilos. Essa ausência de abordagem surpreende, pois existem estilos de vida (e até estéticas) específicos nesses contextos sociais. Por outro lado, também tenho lido muitos textos no noticiário que abordam o universo de bairros periféricos de forma bastante estigmatizada, senão preconceituosa. Além disso, existe uma visão geográfica unilateral relativa ao assunto, pois quase todos os estudos, acadêmicos (ou não), abordam favelas cariocas, o que leva as pessoas a fazerem analogias com outros contextos, supostamente comparáveis. Isso tem consequências desastrosas para a definição de políticas públicas, seja nas áreas de segurança pública, habitação e saúde, seja nas de educação e cultura.

Definitivamente: 1) as favelas cariocas são apenas uma parte do cenário relativo a bairros periféricos, pois em todas as capitais no Brasil há bairros parecidos, 2) nem todos os bairros que, pelo senso comum, parecem ser favelas, pelos moradores são chamados ou percebidos assim e há uma infinidade de outros termos regionais, 3) as favelas (ou seus equivalentes) não são iguais, apesar de existir um discurso nivelador que atribui a todas elas os mesmos problemas e as mesmas características. Aliás, 4) o que mais chama atenção é que parece só haver problemas, nunca há aspectos positivos. Será que também é possível aprender algo com estes espaços sociais ou receber deles algum estímulo positivo? Por todos estes motivos, resolvi trazer reflexões sobre o cotidiano desses locais a partir de minhas experiências de convivência e atuação profissional em bairros populares em Salvador para contribuir para a melhor compreensão deste universo social e cultural ${ }^{4}$. Assumo conscientemente a subjetividade em constante diálogo com dados de parentes, vizinhos e alunos e resultados de pesquisas realizadas nos últimos 15 anos nestes contextos ${ }^{5}$.

De antemão, expresso meu incômodo ao perceber que as realidades destes bairros, em maior parte habitados por classes sociais vistas como de menor poder aquisitivo, habitualmente taxadas como sendo menos instruídas, são associadas intimamente à violência, em geral, como relação direta de causa/ efeito. As visões polarizadas, seja desclassificando os bairros populares como espaços socialmente menos prestigiosos e culturalmente mais pobres, seja enaltecendo o efetivo processo de empoderamento de vários dos seus habitantes, não conseguem dar conta das complexas relações socioculturais cotidianas que permeiam também as questões musicais. Estas se expressam através de outras questões não menos importantes como redes de parentesco e de sociabilidade, expressões tradicionais culturais, presentes em muitos destes espaços, formas de comunicação (pautadas muitas vezes na expressão oral) com valores morais próprios, incluindo códigos de ética específicos.

A vinculação quase exclusiva destes bairros chamados de favela com o tema da violência (entendida como consequência direta do tráfico de drogas) causa a construção de uma perigosa via de argumentação de que a única solução para os problemas decorrentes da violência seria o policiamento ostensivo com a instalação de UPPs (Unidades de Polícia Pacificadora, em Salvador: Bases Comunitárias de Segurança) e medidas repressivas. Ao fazer isso, não estão sendo levados em conta os demais fatores de funcionamento interno dos bairros e as instâncias que adotam esse pensamento perdem a chance de uma abordagem mais profunda, mesmo que mais trabalhosa. 0 mesmo acontece com o discurso baseado em ideias salvacionistas que declaram o suposto poder redentor das expressões artísticas como possibilidade de combate à violência, em especial aquelas vistas como mais alta expressão de 
cultura, tais como a chamada "boa música", balé clássico ou orquestras sinfônicas. Quem nunca é ouvido no meio desse fogo cruzado de convicções e ideologias são as pessoas que moram nesses bairros com percepções bem diferentes daquelas midiaticamente divulgadas ${ }^{6}$.

É notório o desconhecimento que a maior parte da tradicional classe média tem dos agrupamentos urbanos denominados bairros populares. Na verdade, trata-se de mais do que desconhecimento, pois entre muitos reina, além do preconceito, também um medo difuso constante. Isso traz problemas para o diálogo entre os vários segmentos da sociedade brasileira, ainda mais porque essas pessoas, em geral, não se propõem a conhecer os universos desses bairros, o que aumenta a necessidade de trazer informações mais precisas, já que são de fato estes bairros que muitas vezes decidem o caminho da política ${ }^{7}$, além de serem culturalmente ricos e criativos.

\section{O tema na literatura: a proposta metodológica analítica}

Nos últimos anos, tem surgido um número grande de estudos sobre contextos urbanos, certamente impulsionados pela expansão de estudos na área da antropologia urbana e geografia, tais como Barbosa (2009), Coutinho (2011), Feltran (2011), Jovchelovitch (2013), Meirelles \& Athayde (2014), Magnani (2012) e Serpa (2007) e outros que abordam questões de violência, relações de poder, espaço público e cultura juvenil a partir de vários ângulos disciplinares. Porém, quase sempre estas publicações têm se concentrado na realidade carioca (e eventualmente paulista) que, justiça seja feita, parece contar com um alto nível de mobilização comunitária, não somente em torno de questões sociais, mas também voltada para reivindicações políticas, o que explica a maturidade das discussões instaladas. Parece que não existem abordagens equivalentes em outras metrópoles brasileiras ou elas ainda não ganharam visibilidade ${ }^{8}$.

Sobre as possíveis razões desse desequilíbrio representativo e geográfico só resta levantar hipóteses: o caso carioca seria mais visível desde o período no qual o Rio ainda era capital, devido: 1) ao surgimento e à trajetória do termo favela no Rio, 2) à concentração dos meios de comunicação no Rio (do império dos Diários Associados à TV Globo) que gerou maior visibilidade e exposição das realidades locais, 3) à invisibilidade que outras realidades e experiências brasileiras historicamente experimentam, 4) ao maior nível de organização política dos protagonistas cariocas.

Após $2000^{9}$ têm surgido várias publicações que começam a discutir o papel destes espaços de moradia a partir de um novo ângulo, em maior parte oriundos da área de arquitetura e urbanismo (DUARTE, 2009 e 2011; BUENO, 2009 e 2011), geografia, economia, tecnologia e comunicação $^{10}$. Elas oferecem reflexões sobre o poder aquisitivo das classes sociais emergentes (como novos integrantes da classe média) e sua real representatividade nos meios de comunicação, bem como analisam o recente interesse dos "moradores do asfalto" pelos morros, impulsionando um movimento de turismo intra urbano que no Rio de Janeiro se desloca morro acima ${ }^{11}$.

Porém, curiosamente, o mesmo interesse ainda não tem surgido na área de artes, especialmente música, algo que este texto se propõe a fazer de forma introdutória a partir do campo crítico da etnomusicologia ${ }^{12}$. Mesmo que sabidamente exista uma infinidade de expressões musicais ligadas ou oriundas de contextos sociais de bairros populares ou favelas, poucos estudos têm se debruçado sobre as complexas relações entre música, agentes e espaço, concentrando-se, em geral, mais na música como fenômeno sonoro (ou reduzindo-a apenas às letras) ${ }^{13}$ do que como fenômeno social, cultural ou histórico. Isso difere da área de teatro, artes plásticas e literatura que há várias décadas não apenas inserem o espaço urbano no seu universo conceitual e de ação através de experiências como teatro aplicado ou intervenções artísticas urbanas, mas também discutem estas questões (COUTINHO, 2011; BRITO, 2012) ${ }^{14}$. Mas, até esses textos surgiram em número maior relativos a bairros cariocas do que a outras cidades do Brasil, deixando certa lacuna na compreensão desses fenômenos, intimamente vinculadas ao crescimento urbano vertiginoso de todas as cidades brasileiras. Exceções desse quadro apontado na área de artes/ música são alguns estudos recentes que abordam estilos musicais populares como o tecnobrega (AMARAL, 2009), o trabalho de ONGs em contextos sociais (KLEBER, 2014; HIKIJI; CAFFÉ, 2013) ou trabalhos na área de educação que começam a se debruçar 
sobre relações socioculturais e educativas (PAIVA; BURGOS, 2009; CAFFÉ; HIKIJI, 2012), embora não enfatizem o contexto social como aqui proposto.

Assim, consciente da amplitude e problemática conceitual, o presente texto busca um olhar diferente, debruçando-se sobre os bairros populares/ favelas por entendê-los como lugares geográficos e sociais importantes para a compreensão das cidades brasileiras hoje, o que inclui a sua rica vida cultural, sem discutir a obviedade do fato de os bairros populares serem resultado da exclusão e desigualdade (DAVIS, 2006), associadas à questão de violência (ZALUAR, 2006; FELTRAN, 2011). Ao contrário, parto das contribuições que estes lugares de convivência social e cultural podem oferecer na reflexão urgente sobre o espaço urbano, não como problemas, mas como possíveis alternativas para a vida urbana, a partir do olhar sobre bairros populares em Salvador.

Proponho uma mudança de foco, observando a partir do lócus das vivências culturais (e outras) em bairros populares como espaços extremamente ricos de experiências, necessárias para pensar também entraves e desafios atuais na área de educação, mobilidade urbana e políticas culturais, apesar da existência de muitos textos específicos sobre cada uma destas questões. Entendo também que o local, em geral visto como algo insignificante, perante questões de ordem mais geral e até global, pode ser algo potencialmente subversivo, devido ao seu poder de contestação. Assim, proponho enfatizar experiências e conhecimentos locais como contribuições importantes para a reflexão sobre estruturas sociais e políticas maiores.

Não obstante, a complexidade do tema requer um trânsito por várias áreas de conhecimento, o que traz dificuldades e desafios interpretativos desse universo tão amplo. Pois, análises segmentadas por áreas de conhecimento não conseguem dar conta das realidades múltiplas destes bairros que vão além de questões de saneamento básico, acesso a transporte, saúde, educação ou questões de violência. É muito importante deixar claro que os bairros populares não são "o" problema em si, nem a causa de problemas urbanos. Ao contrário, eles apenas evidenciam problemas históricos em relação ao funcionamento das cidades e as crônicas relações de desigualdade de seus moradores, mas, a meu ver, também podem oferecer contribuições para pensar vários dos problemas urbanos e sociais brasileiros atuais a partir de novos ângulos.

Surge, assim, o desafio de iniciar uma discussão com um foco propositalmente fora de áreas disciplinares específicas, mas a partir do lócus geográfico/ histórico destes bairros e das estratégias de convivência social e cultural dos seus moradores, entendendo esses espaços como organismos sociais extremamente vivos. É importante ressaltar que vivo há mais que 25 anos em um tradicional bairro popular em Salvador, o que aguçou e mudou minha percepção de vida relativa à complexidade das relações sociais assimétricas entre grupos étnicos/ raciais e suas causas históricas, também notando a reduzida presença de reflexões no âmbito acadêmico. Concentro a minha análise em bairros populares em Salvador que já têm certo tempo de existência, chegando a 100 anos ou mais. Não incluo invasões ou ocupações recentes e tampouco conjuntos habitacionais construídos nos últimos anos, em geral mais distantes dos centros urbanos, em parte até para abrigar pessoas relocadas de bairros populares/favelas.

\section{Definições e conceitos: seus caminhos descaminhos}

Mas o que são, afinal, bairros populares? ${ }^{15}$ Uso esse termo para me referir a bairros geograficamente e/ou socialmente periféricos em Salvador, devido ao uso diferenciado que se faz dele na Bahia em relação ao termo favela (SERPA, 2007a; 2007b); Cadernos da Cidade, 2009 ${ }^{16}$. Este último termo, que parece ter recebido nos últimos anos uma conotação positivada no Rio, como expressão de autoafirmação (COUTINHO, 2011; GONÇALVES, 2013), inicialmente é específico para designar os bairros situados nos morros cariocas. De lá, espalhou-se para várias regiões do país, designando habitações em situação parecida, certamente devido à situação de destaque da cidade como capital até os anos 1950 (ver ZALUAR; ALVITA, 2006, p.7-15). Desta forma, uso o termo "bairro popular" como sinônimo para bairros simples em relação ao acabamento de suas construções, mas já consolidados há décadas e, nesse sentido, diferentes das assim chamadas invasões. Estas últimas, pelo menos em Salvador, 
em geral, são chamadas de "favela", por serem improvisadas e temporárias e, desta forma, bem mais simples do que os bairros populares que já passaram por processos de consolidação e contam com ((boa) parte dos) serviços básicos e infraestrutura, necessários para permitir uma vida mais estruturada ${ }^{17}$. Apesar disso, nas falas de alguns representantes mais jovens desses bairros, em tempos recentes o termo favela e/ou gueto ${ }^{18}$ também está presente como forma de auto representação, apesar de não ser nomenclatura unânime entre os moradores.

O termo favela é atribuído aos primeiros ajuntamentos dos ex-combatentes da Guerra de Canudos, retornados daquela batalha nos últimos anos do séc. XIX, na expectativa de conseguirem um local de moradia, prometido anteriormente. Sem concretização, fê-los ocupar os locais que conhecemos até hoje como tais (GONÇALVES, 2013, p. 44), definidos como agrupamentos urbanos com ar de transitoriedade e de precariedade. Mas é sabido que, a partir da busca desenfreada pelo progresso, a sociedade brasileira começou a estigmatizar não apenas os locais chamados favelas, mas também os seus habitantes (ou o contrário), um quadro que se mantêm até hoje.

Não por último, também o IBGE tem se dedicado ao tema, a partir de um termo esdrúxulo, tecnicista e, até, preconceituoso. Nos dados do censo de 2010, publicados no final de 2011, há uma série de fotos que mostram bairros em várias cidades brasileiras com as mesmas características que os bairros populares aqui discutidos, porém, definidos como "aglomerados subnormais" = lugares construídos por processo de ocupação ilegal de terra e desprovidos de indicadores como ruas largas ou planejamento oficial, entendidos como fundamentais para o bem estar:

a) Ocupação ilegal da terra, ou seja, construção em terrenos de propriedade alheia (pública ou particular) no momento atual ou em período recente (obtenção do título de propriedade do terreno há dez anos ou menos); e

b) Possuir pelo menos uma das seguintes características:

- urbanização fora dos padrões vigentes - refletido por vias de circulação estreitas e de alinhamento irregular, lotes de tamanhos e formas desiguais e construções não regularizadas por órgãos públicos;
- precariedade de serviços públicos essenciais. (BRASIL, 2011a, p.17, 2011b, p.27) ${ }^{19}$

Esse conceito parece bastante problemático, pois apresenta definições questionáveis: qual seria a diferença legal entre condomínios que se "gabam" construir "em área preservada" para oferecer todo conforto aos seus futuros moradores (e que, consequentemente, devem ter uma relação bastante conflituosa com áreas verdes e/ou públicas ${ }^{20}$ ) e bairros que se formaram a partir da fixação de moradias de escravos libertos e trabalhadores que permaneceram nas áreas antes pertencentes aos seus antigos senhores no final do séc. XIX, como é caso do bairro onde resido? Diferenças existem, mas não necessariamente no aspecto legal ${ }^{21}$, e como diz Bueno (2009, p.49): "nem tudo que é irregular é precário".

A associação da ideia de irregularidade de alinhamentos dos terrenos em formas desiguais, vias de circulação limitadas, vinculadas à precariedade de serviços públicos essenciais apenas com bairros populares parece questionável. Pois, o condomínio de luxo que começa pela construção de largas ruas, muitas vezes sinuosas, colina acima e abaixo, pelas quais nunca passa um transporte público, impossibilitando o acesso aos cidadãos comuns (incluindo os que por lá trabalham, mas não residem) não atende a estas questões. Portanto, não é o planejamento em si que faz do condomínio um lugar habitável e socialmente/ ecologicamente correto. Por outro lado, há os tantos conjuntos habitacionais criados por projetos governamentais, planejados, mas com problemas de transporte e infraestrutura, sem acesso a serviços de saúde e educação, tais quais os condomínios de luxo, embora nos últimos a densidade populacional seja bem menor. Supõe-se que as pessoas dos condomínios não precisam do transporte público por habitualmente se locomoverem de carro. Por outro lado, certamente 80 das escolas públicas no Brasil estão localizadas em bairros populares e demais "aglomerados sub-normais"22, localidades que, assim, no quesito educação seriam atendidos por serviços públicos (ou não, se questionarmos e qualidade do sistema educacional), diferente de condomínios de luxo.

Portanto, apesar de reconhecer a dificuldade de abranger conceitualmente a diversidade 
apresentada a seguir, chego à conclusão de que os quesitos do IBGE são, no mínimo, arbitrários, pois não estabelecem critérios que sejam aplicados de forma igual a todos. A definição do IBGE se torna ainda mais tendenciosa ao afirmar que conjuntos maiores de aglomerados subnormais "formam 'manchas'" [com aspas no original] de aglomerados subnormais (BRASIL, 2011a, p. 17-18). Em outras palavras, favelas e bairros populares são considerados chagas da sociedade moderna urbana, pelo menos do ponto de vista da classe média brasileira ${ }^{23}$.

\section{História e geografia dos bairros populares}

Como ficou evidente na definição do IBGE, uma das questões principais que permeia as discussões parece ser a da titularidade do solo, sempre vista como inexistente em relação aos bairros populares. Ela remonta ao período dos primeiros levantamentos imobiliários no Brasil, a partir da Lei 601 de 1850, chamada Lei de Terra ${ }^{24}$. Certamente ainda faltam análises sobre a história da ocupação do solo brasileiro a partir da percepção dos grupos populacionais menos privilegiados, sejam nos moradores de áreas urbanas ou rurais. A discussão do espaço urbano carece de uma revisão crítica dos pressupostos para as definições de titularidade de terras, algo a ser feito com urgência para avançar de fato nas discussões sobre o espaço urbano moderno, seus usos e suas funções, discussão iniciada por Gonçalves (2013). Além disso, é necessário definir e compreender os limites (reais e imaginários) de espaços geográficos como bairros ou de comunidades dentro de um bairro maior. Certamente as percepções dos seus moradores são diferentes daquelas dos técnicos das prefeituras, sendo que a opinião dos últimos se sobrepõe, em geral, a dos primeiros.

Enquanto os centros administrativos e comerciais de cidades já mudaram inúmeras vezes de lugar e, com isso, também a localização de lugares das moradias mais privilegiadas, as menos privilegiadas parecem manter-se por muito mais tempo nos mesmos lugares, embora passem por constantes requalificações e ressignificações. Elas até podem tornar-se cobiçadas pela especulação imobiliária, por terem "perdido" sua anterior localização geográfica periférica e, devido ao crescimento urbano, terem se transformado em locais situados mais ao centro, tornando-se assim sujeitas a processos de gentrificação, fenômeno que atinge pouco os bairros populares mais antigos, aqui analisados. Essa complexa relação entre espaço físico e pessoas, interesses e direitos, mostra que o termo periferia (seja ela geográfica ou social) precisa ser ressignificado com frequência ${ }^{25}$. Além disso, atributos de qualidade e valor de terrenos (devido à sua localização) mudam sempre, conforme os interesses, possibilidades e impedimentos que fazem surgir moradias dos vários segmentos populacionais. Assim, os bairros populares se destacam pela sua capacidade em adaptar-se ao que for necessário, em geral, sem sair do lugar.

Mas há, de fato, diferenças entre as trajetórias de surgimento e planejamento das cidades brasileiras e as formas de ocupação de seu solo durante os processos de expansão e crescimento urbano, incluindo topografias muito diferentes e populações étnicas em posições sociais bastante desiguais. Muitas vezes os moradores dos bairros populares mantiveram e mantêm conhecimentos sobre técnicas, materiais e conceitos de construção específicos, diferentes entre as regiões brasileiras (atendendo também às diferenças climáticas). São práticas hoje designadas como arquitetura vernacular: as técnicas de construção de moradias ribeirinhas na região amazônica, também presentes em Manaus e Belém, diferentes daqueles do sertão nordestino, do Paraná ou do Mato Grosso, todos bem diferentes das construções habituais com alvenarias das capitais brasileiras, embora os fluxos migratórios internos no país também tenham mesclado esses conhecimentos ${ }^{26}$.

Não se pode entender o perfil dos bairros populares em Salvador sem levar em conta as redes de relações pessoais que antecedem, permeiam e acompanham qualquer outra questão. Diferente de bairros de edificações verticalizadas, as facilidades de contatos entre as pessoas nestes bairros remontam historicamente a formas de sociabilidade decorrentes da ocupação do solo de longas datas, em geral, protagonizados por pessoas negras, caboclas, excluídos da esfera de decisão política durante séculos. Em geral, estas populações buscaram áreas mais distantes, inicialmente menos cobiçadas, para driblar a dificuldade de conseguir lugares de moradia. Não deve ser esquecido que os precursores dos atuais bairros populares em geral se instalaram 
em locais que garantiram sua subsistência, áreas compartilhadas às vezes com algumas pessoas mais abastadas que mantinham nessas regiões pequenas propriedades rurais para a produção de alimentos, atendidas por alguns escravos que mais tarde permaneceram nas regiões como libertos (o que antes da abolição até pode ter sido uma estratégia de proteção). Quer dizer, bairros populares hoje situados em regiões centrais da cidade, um século atrás eram tão periféricos como outros bairros hoje considerados periféricos.

Com isso, os bairros populares fazem parte do processo da expansão urbana e são elementos importantes para entender a história das cidades. Isso é algo muito pouco observado, pois, em geral, são entendidos como lugares sem história (pela sua suposta instalação recente, a imaginada ausência de documentos oficiais e pela dificuldade em trabalhar com história oral). Mas parece tratarse mais de uma falta de interesse do que de uma efetiva ausência de fontes de toda natureza. As pesquisas sobre estes locais quebram, certamente, paradigmas metodológicos, pois nos obrigam a sair do pensamento de recortes temporais específicos, como são comuns na periodização da história ${ }^{27}$.

Os termos usados para referir-se a esses espaços também mudam. Cito como exemplo o bairro no qual resido, um bairro com população predominante afrodescendente, tido como de baixa renda e em situação de vulnerabilidade social, situado na região central da cidade que, em artigos de jornal de 80 anos atrás, é chamado de bairro pobre e proletário, mas não de favela (Estado da Bahia, 26/7/1937). Já em documentos históricos anteriores, de meados e do final do século XIX, locais específicos do atual bairro já são tratados pelas mesmas denominações topográficas que ainda são conhecidas hoje. Isso reforça a questão de pertencimento geográfico/ local como um dos elementos preponderantes, talvez mais do que outros, pelo menos em relação aos bairros populares de Salvador que já contam com mais de 100 anos de existência ${ }^{28}$.

É comum encontrar nesses bairros antes tidos como "proletários" (termo usado até poucos anos atrás nos carnês de IPTU) várias subáreas que mesclam diferentes padrões de construção. Assim, há um contínuo entre casas mais sofisticadas e outras muito mais simples, e até áreas com conjuntos habitacionais construídos nos anos 1970. Em uma mesma rua pode haver diversos padrões de construção, dividindo bairros populares em áreas mais antigas e mais recentes. Esse quadro não difere de outros bairros também antigos, embora não necessariamente tidos como populares, tantas vezes alternando casas/prédios bem cuidados com outros fechados ou até abandonados (hoje cobiçados por especulação imobiliária e movimentos sociais dos sem teto ${ }^{29}$. Contudo, o abandono de imóveis em bairros populares é raro, por não incidir especulação imobiliária e sempre ter pessoas que prontamente alugam qualquer imóvel. O que talvez cause espanto é a impossibilidade de classificação, a organicidade desses bairros que crescem no seu tempo e ritmo, sem pedir licença aos órgãos da prefeitura, expressando outros padrões de operacionalidade, mesmo que ainda não entendidos pelos órgãos.

Os antigos bairros populares em Salvador se mantêm há muito tempo, às vezes até 150 anos, nos mesmos lugares, sempre crescendo com uma vida pulsante, cheios de pessoas enquanto as regiões centrais e anteriormente nobres, ao mudarem de função e perfil, muitas vezes caíram em decadência. Pois, se naqueles existe uma divisão mais rígida entre as esferas de moradia, de comércio e de trabalho ${ }^{30}$, é a junção de funções que nos bairros populares afere tanta vida ao seu cotidiano. São verdadeiramente complexos multifuncionais/ multiuso, termo que aparece nas propagandas imobiliárias dos últimos anos para outras estruturas, algo que os bairros populares reúnem há muito tempo, antecipando o conceito e comprovando a sua eficácia. Assim, são bairros que estão constantemente em movimento, questão a ser aprofundada ainda.

As moradias típicas, originalmente casas térreas pequenas, hoje, sempre mais verticalizadas, alcançam 2, 3 ou 4 andares, muitas vezes ocupando os antigos quintais. Em geral, são habitados por filhos, sobrinhos e netos, a não ser que sejam alugados, como fonte de renda dessas famílias em ascensão, o que muda aos poucos o perfil desses bairros. Pois, se antes todos se conheciam por serem, em geral, famílias extensas que mantinham laços de parentesco e proximidade, há novos moradores que se inserem (ou não) nessa rede de relações sociais, muitas vezes ficando apenas por poucos meses. 
É importante ressaltar o processo de formação de bairros populares e da relação que os seus habitantes têm com ele: a maior parte dos habitantes mora neles há várias gerações e continua morando lá por causa de algumas qualidades que percebem, entre elas a proximidade de redes sociais existentes, o sentimento de pertencimento e acolhimento, facilidades devido à proximidade com estabelecimentos comerciais $\mathrm{e}$ a presença de tradições culturais. Por outro lado, podem faltar outros serviços que são reclamados e atendidos apenas com certa pressão para assim conseguir postos de saúde, escolas públicas em número suficiente, sistema de transporte público e coleta de lixo regular. Estes benefícios hoje já existem em muitos bairros populares de Salvador, além de escolas particulares, igrejas, comércio e academias (também, depósitos de bebidas), acompanhando a ascensão social das pessoas e seu novo padrão de vida ${ }^{31}$.

Assim, os bairros populares crescem sempre mais (e se multiplicam), mudando de configuração interna, até reduzindo o seu espaço verde, público ou não, mas eles não mudam de lugar (a não ser que ocorram desapropriações pelo estado para construção de alguma obra pública). Diferente disso, muitos bairros habitados pela classe média passam por outro processo: as pessoas mudam de lugar de moradia conforme novas modas imobiliárias. Esse processo deixa tradicionais bairros nobres ociosos e até "abandonados", vistos só há pouco tempo como novas possibilidades de requalificação urbana. Por outro lado, muitas vezes os novos bairros ricos fazem surgir novas ocupações ao seu redor, mantendo o ciclo de dependência mútua e suas polarizações.

\section{Bairros Populares e suas características socioculturais}

Mas por que abordar estes bairros ao pensar em cultura e o que, de fato, existe em termos de cultura/ música nesses bairros, historicamente vistos como desprovidos de tudo e quem seriam as pessoas que protagonizam essas experiências culturais diversas? Muitas pessoas que moram nestes bairros em Salvador, majoritariamente a população negra, nas últimas décadas conseguiram conquistar maiores níveis de instrução, apesar de terem frequentado, em geral, escolas públicas, que atendem a maior parte dos bairros populares. Até pouco tempo atrás era mais raro quebrar o círculo vicioso da falta de oportunidades e conseguir uma formação, mas hoje há um número crescente de pessoas que conseguem seguir outros caminhos de formação, ingressando em universidades públicas através de políticas de cotas (ou não) ou, então, estudam em instituições particulares. O curso universitário é um importante passo na mobilidade social, embora, diferente de jovens de classe média, a maior parte dos jovens concomitantemente já está trabalhando para poder frequentá-las. Assim, as pessoas tornam-se socialmente mais visíveis, não por último por passarem com mais frequência dos limites geográficos do seu bairro de origem, trabalhando em outras regiões, em empregos mais estáveis ou temporários, transitando em áreas antes mais frequentadas por pessoas de classes sociais mais altas. Mesmo assim, elas mantêm os laços sociais com os contextos de origem, permanecendo no "seu" bairro, apesar de sua nova condição social que muitas vezes até Ihe permitiria viver em outros bairros. Mas a opção de muitos é permanecer, o que já demonstra um primeiro paradoxo. Os bairros populares não são apenas "depósitos" de pessoas que não têm condições financeiras para morar em outros lugares, socialmente mais prestigiosos, ao contrário, eles optam por morar nestes bairros, por vários motivos a serem discutidos ainda. É claro, que também há vários outros que, assim que Ihes for possível, deixam o seu bairro de origem para morar em outro local que expresse visivelmente a sua ascensão social. E, finalmente, há aqueles que migram de um bairro popular para outro, às vezes, por ficar devendo aluguel, criando problemas para as partes envolvidas, os donos e os inquilinos ${ }^{32}$.

Assim, os moradores mais antigos ficam e veem os inquilinos passar com uma rotatividade de alguns meses a um ano. Isso pode alterar até regras não escritas de convivência e de civilidade, regras que dizem respeito ao espaço público, que em geral é coletivo, e seus limiares com o espaço particular: serviços que em muitos prédios são terceirizados, incluídos no valor do condomínio, nos bairros populares são feitos pelas pessoas de forma individual ou, em outros momentos em mutirão. Varrer a porta de casas térreas faz parte dessas regras básicas, bem como organizar o que acontece na própria porta, já que o "dono" daquele pedaço de rua se sente responsável e incomodado por algo que acontece na "sua porta", pela qual 
zela. Isso pode levar a reclamações com o "invasor" de sua "privacidade pública" como lixo, crianças que brincam com altas vozes ou usam brinquedos que provocam ruídos. Mas nem sempre as pessoas aceitam essas reclamações, replicando-as com frases como: "a rua é pública", ou simplesmente usando o argumento da anterioridade de sua existência naquela rua, argumentando que sua "senioridade" Ihes afere direitos especiais, o que fica evidente em momentos de festas particulares que, pelo volume de som, provocam incômodos para os vizinhos.

Não obstante, essa disputa por espaços e reconhecimento vai além de possíveis incômodos causados por crianças ou lixo, também há crescentemente incômodos causados por equipamentos tecnológicos que operam a partir de outra lógica, presentes também em outras partes das cidades. Trata-se do dono do carro com um "trio elétrico" móvel no fundo de seu automóvel que é expressão de poder aquisitivo, masculinidade e poder, e "com ele ninguém pode", caso alguém ouse reclamar ${ }^{33}$. Bem como há equipamentos de som que passam dos limites aceitáveis, mas a proximidade de laços entre os vizinhos muitas vezes inibe a expressão do incômodo sentido pelos vizinhos. Assim, sobrepõem-se velhas e novas formas de relações sociais, há alguns anos permeadas por novos códigos de comportamento, protagonizados por jovens de 15 a 25 anos, em parte envolvidos pela rede subterrânea de violência ligada ao tráfico que eclode em alguns momentos ${ }^{34}$.

No meio dessa delicada rede de forças entre pessoas que se conhecem, se consideram (ou não) e dividem os mesmos espaços sociais, há além dos festejos de datas particulares (como aniversários) outras que são marcadas pelo calendário de festas populares, embora estas tenham passado por certo declínio, não por último devido às mudanças no campo religioso, social e ambiental. Até poucos anos atrás, era comum poder presenciar inúmeras festas ligadas ao calendário católico, como Santo Antônio, São João, São Pedro, São Roque, São Lázaro, Santa Luzia ${ }^{35}$, Natal, Dia de Reis. Estas festas de caráter religioso tinham um importante componente público, além de envolver a esfera familiar, contando com procissões e casas abertas para receber visitantes e amigos. Entretanto, o númerocrescentede moradores evangélicos trouxe uma nova configuração de valores religiosos e de referências sociais, esvaziando as antigas formas de sociabilidade que muitas vezes também incluíam comidas típicas, agora rotuladas como impróprias e até condenáveis. Cito como exemplo o caruru, comida típica na Bahia, ofertada nos festejos de Cosme e Damião, vinculada à religiosidade afrobaiana, bem como a farta mesa de outras comidas típicas de origem afro-baiana no almoço da Sexta-feira Santa baiana ou, então, as comidas tradicionais de São João. Se antes na Bahia quase todos eram católicos e outra parte (também) do candomblé, com trocas culturais constantes, hoje este espectro ganhou outra dimensão, com uma diversidade religiosa muito maior do que algumas décadas atrás que inclui, além dos evangélicos (das mais diversas denominações), espíritas, harekrishnas, messiânicos, daimistas e até budistas ${ }^{36}$. Isso interfere nas formas de convivência, segmentando os vários grupos populacionais que, agora, compartilham hábitos culturais apenas entre as pessoas da mesma religião, em geral de forma mais reservada, acontecendo em espaços internos. Contudo, mesmo com a fragmentação e diversificação de credos, a religiosidade em si não diminuiu, ela continua sendo um dos elementos fortes na vida social dos bairros populares com suas datas festivas ${ }^{37}$.

Por outro lado, nascimento, doença e morte ou, então, aniversários e os dias de jogos de futebol, assistidos pela TV (com aparelhos colocados na rua) e acompanhados por churrascos, são oportunidades para encontros familiares ou de amigos, marcados para juntar-se por aquele motivo ou ocorrendo de forma espontânea. Todos esses momentos servem para reforçar constantemente os laços familiares, de vizinhança e de amizade. É claro que, quanto mais numerosa a família for, essa rede é mais extensa, enquanto as redes daqueles que são de fora são mais reduzidas, muitas vezes recriadas a partir de relações de compadrios e relações de parentescos por afinidade e de consideração ${ }^{38}$. A força da rede de parentesco e de vizinhança constitui um importante capital social tal qual ela existe em outros substratos da sociedade. É nesse contexto que acontecem, no meu bairro e outros parecidos, tradições musicais como samba junino, samba de roda, festas nas casas de candomblé, além de atuarem vários grupos de pagode e outras expressões, formando uma densa complementariedade de trajetórias e 
estilos musicais, alguns antigos ainda em vigor e outros mais recentes, incluindo grupos musicais ligados ao universo evangélico.

Mas, qual seria a visão de cultura/ vivência cultural dos próprios moradores desses bairros? Além das dificuldades conceituais atreladas a ela, é diferente daquilo que outros grupos sociais da sociedade entendem. Existe um grave problema ligado ao senso comum, que subestima a vida e os interesses dos moradores de bairros populares em três sentidos, supondo que: 1) as expressões culturais desses bairros per se não seriam cultura, 2) todos os seus moradores teriam o mesmo gosto musical e, 3) estariam esperando que alguém trouxesse algum tipo de expressão cultural, desta forma "melhorando" a vida das pessoas através dessa nova vivência cultural/ musical. Esse pressuposto é extremamente preconceituoso e paternalista, porque não reconhece a possibilidade de existirem práticas culturais locais e por supor que há culturas ou estilos musicais melhores/ piores ou superiores/ inferiores e as pessoas estariam infelizes com aquilo que praticam. Além disso, entende as pessoas como incapazes de criarem formas de expressão próprias e significativas para elas a partir de iniciativas de diálogo e apropriações musicais que partem das próprias pessoas.

Nos últimos anos, têm sido criadas políticas de formação de plateia, dirigindo-se também a pessoas oriundas de bairros populares, porém, nem sempre bem sucedidas, pois os moradores de bairros populares não vão ao teatro apenas porque Ihes falte o hábito. Tampouco deve se pressupor que ao "levá-los" ao teatro, automaticamente elas vão (ou devem) gostar das apresentações, o que seria um erro. Não é a suposta falta de hábito da convivência com o teatro que os faz preferirem outras expressões, algo que muitos produtores culturais e instâncias governamentais ainda não entenderam: o que as pessoas gostam, em geral, está intimamente ligado a redes de sociabilidade, mas as suas redes e não as de outras pessoas com outros modos de vida. Assim, elas podem ir ao cinema, a um show, curtir o carnaval, mas a partir de critérios próprios, não necessariamente iguais às propostas de mediadores culturais que representam as secretarias de cultura em ações de formação de plateia.
Além disso, há outro fator importante: as expressões culturais existentes nos bairros populares, em geral, incluem o corpo como uma das formas de expressão tão importante quanto o som musical e a comunicação oral. Por isso, muitas vezes não faz sentido para as pessoas, ao serem levadas ao teatro, assistirem caladas e sentadas a um concerto, supostamente de nível mais elevado (na percepção burguesa), pois as regras de apresentação não condizem com a forma de livre expressão, resumido no termo brincadeira, que muitas experimentam nas suas práticas musicais, seja o pagode, funk, tecnobrega, samba e muitas outras ${ }^{39}$. Parece que esse detalhe importante passou despercebido de muitos formadores de plateia que acreditam existir uma fórmula simples para a junção da cultura e seu público (LÜHNING, 2014).

Portanto, se, na percepção de muitas pessoas, a cultura acontece (apenas) nos teatros, museus e outros espaços consagrados, o que seria aquilo que acontece nos bairros populares? Estamos diante da questão chave que apresenta um problema conceitual que pressupõe consequências para a construção de políticas públicas em várias áreas: em vez de tentar entender o modus operandi cultural de bairros populares, supõe-se que eles não têm expressões culturais próprias ou apenas de importância menor, precisando de esforços para "evoluírem" culturalmente como único caminho possível. Parece que a maior parte das pessoas não discorda dessa visão (pois não há contestações) e, de fato, acha que a visão dominante de cultura com suas expressões teria uma capacidade de sublimação.

Muitos dos bairros populares de Salvador misturam de forma equilibrada estruturas habitacionais, comércio, escolas e até serviços, o que traz bastante comodidade para os moradores que não precisam se deslocar para resolver questões básicas. Não há uma divisão entre esfera de moradia de comércio, lazer e trabalho, tudo se funde (o que também pode trazer problemas), mas cria-se uma relação quase indissociável dessas esferas, o que permite formas de integração de vários níveis. Portanto, esses bairros nunca ficam parados, vazios, como os centros comerciais de muitas cidades, mas sempre em movimento e são também centros de fontes sonoras das mais diversas. ${ }^{40}$

\section{Os sons que percorrem o espaço}


Do compartilhamento de hábitos também faz parte a permeabilidade sonora de dentro para fora e vice-versa e, com essa onipresença sonora, ouve-se (de) tudo, queira se ouvir ou não. Esse cenário sonoro talvez seja uma das características principais de bairros populares, mesmo que exista algo em escala bem menor também em prédio, com a diferença que eventuais problemas lá são resolvidos através da interferência de um síndico, sem o envolvimento tão direto das pessoas. Nos bairros populares existe uma paleta de sons mecânicos àqueles de origem humana: do chiado da panela de pressão, do motor do liquidificador e da máquina de lavar a gritos e gargalhadas, vozes de crianças brincando ou brigando, mães chamando seus filhos e aparelhos de som disparando. Esses sons contrastam ainda com estouros de fogos de artifício (soltados por diversos motivos), a depender do lugar também com estampidos de tiros, com o canto de pássaros, o zumbido de cigarras e os latidos de cachorros, sons de carros e motos, assim compondo um cenário auditivo cotidiano bastante diversificado. Não deve ser esquecido o som penetrante de helicópteros, que se sobrepõe ao diversificado espectro sonoro dos bairros, muitas vezes voando por longos períodos em círculos sobre áreas que, por algum motivo, estão "na mira"41 da atenção. Trata-se de helicópteros da polícia e de canais de TV que promovem um tipo de jornalismo sensacionalista, acompanhando pelo ar ações diversas, policiais ou não. A sua insistência faz com que pareçam "urubus mecânicos", embora muito mais barulhentos do que as aves ${ }^{42}$.

Contudo, o som não alcança os ouvidos apenas de forma direta e de fontes sonoras identificáveis: a propagação do som também ocorre pelo vento marítimo constante em Salvador, trazendo os sons de atabaques de um terreiro de candomblé próximo, de um tamborim, tocando com seu timbre agudo uma clave de samba em algum ensaio de samba, a voz distorcida do sermão de uma igreja evangélica, além de rajadas do som amplificado de alguma festa. Além disso, ainda existe o som do eco entre as construções, devido ao fato de elas estarem muito próximas, em ruas estreitas, colocando desafios para qualquer físico ou arquiteto, caso queira dedicar-se a questões de acústica. Isso é ainda mais acentuado quando os bairros populares estão localizados em morros com ladeiras íngremes ou nos dois lados de grandes vales (comum em Salvador com sua topografia especifica), que cortam esses bairros através de (sempre mais) largas avenidas destinadas ao transporte automobilístico que também é fonte de vários sons.

Contrário ao estereótipo de que todos os moradores de bairros periféricos soteropolitanos do início do milênio gostam de pagode e só ouvem este estilo ou todos os moradores de favelas cariocas estariam curtindo funk, é importante ressaltar que existe a mesma variedade de gostos ou preferências musicais como em outros bairros, mesmo que as ênfases possam ser diferentes. Chamo isso de compartilhamento auditivo ativo que, além de ser espacial, também é inter- e intrageracional: o melhor exemplo é a casa de um de meus vizinhos: enquanto o avô e um de seus filhos curtem as músicas dos anos 50 , em estilo romântico, além de arrocha ${ }^{43}$, um dos genros é fã aficionado de rock brasileiro, reggae e blues, e seu filho, o neto, ouve rap brasileiro e seus amigos ouvem pagode. Em geral, cada um tem o seu horário, sendo raro ter mais do que um ou dois aparelhos de som ligados simultaneamente. Essas misturas e convivências auditivas acontecem com muita frequência em outras casas também, sem que haja protestos. Eventualmente esses sons se misturam com a música gospel preferida por uma das vizinhas ou então com os cânticos de candomblé que um grupo de jovens, frequentadores de uma casa de candomblé recém-criada, entoa enquanto passa na rua, provavelmente para marcar espaço em um cenário sempre mais composto por vizinhos evangélicos ${ }^{44}$. Os terreiros de candomblé nos bairros geralmente ficam em áreas residenciais, tendencialmente mais recuados e até escondidos, enquanto as igrejas tendem a ficar nas ruas principais, visualmente mais perceptíveis. Assim, é possível ouvir de tudo, mesmo que haja claras preferências pessoais e restrições religiosas da parte de algumas pessoas para ouvir certo estilo de música.

Além disso, fica perceptível que pessoas mudam de preferências musicais e que há a constante negociação do espaço sonoro devido à saída de moradores ou chegada de novos vizinhos oriundos de outros lugares (do interior, p. ex.) que trazem suas ( $p$ )referências musicais (vivenciais ou 
midiáticas), misturando música caipira, sertaneja e gospel com as tradições locais afro-brasileiras, assim "diluindo" a sua preponderância histórica. Músicas com letras são preferidas, que, ao mesmo tempo, não são o mais importante, pois as letras em inglês e francês dos reggaes apreciadas, não são entendidas ou ouvidas pelo significado. Já as letras de pagode, muitas vezes criticadas como machistas por movimentos feministas, não causam espanto à maioria das mulheres dos bairros populares que fazem outras leituras. Em geral, as pessoas ressaltam que o mais importante das músicas de pagode é o ritmo, a possibilidade de transformá-lo em movimento corporal, antes de qualquer análise das letras. Músicas de pagode também podem fazer referências ao modo de vida dos bairros populares com posicionamentos de crítica social velada, por alguns até chamado de pagode social ${ }^{45}$.

Além desses posicionamentos críticos de uma parte dos pagodeiros, outros acontecem no círculo do teatro e das artes visuais, pois nos bairros populares, há outros artistas, além do pagode. Há várias "galeras" que lidam com diferentes linguagens das artes performáticas e elaboram discursos críticos, também através do grafite e do hip-hop. Mas todos esses contextos de expressão artística basicamente são masculinos, não há cantoras de pagode e só poucas meninas ou mulheres envolvidas com movimentos de grafite; só na esfera do teatro há uma participação feminina mais expressiva. Quais os fatores que levam à consolidação de grupos de teatro, de hiphop ou outras expressões, em alguns bairros mais do que em outros, é difícil determinar. Também é imprevisível o que faz as pessoas retomar ou manter expressões musicais tradicionais como grupos carnavalescos e de samba. Ainda assim, todas elas convivem lado a lado nos bairros e, às vezes, as pessoas participam de mais de uma expressão ou tradição.

Além dos sons, há as sensações olfativas: do odor de lixo espalhado ou não recolhido ao frequente cheiro convidativo de comidas, sendo preparadas a quase qualquer horário do dia e da noite, envolvendo olfativamente as pessoas que assim, de fato, estão vivendo uma densidade de sentidos. Muitas vezes elas remetem também a comidas tradicionais, especialmente aquelas do contexto afro-brasileiro, por sua vez ligadas a momentos festivos de tradições musicais e ao compartilhamento coletivo como o já mencionado caruru. Desse modo, o tempo todo, ao viver e pensar em cultura todos os sentidos estão sendo aguçados através de uma multiplicidade e simultaneidade de estímulos.

$\mathrm{Na}$ composição sonora e sensorial dos bairros populares ainda há a presença frequente de vendedores ambulantes que mercam de vassouras e detergente a frutas, peixe, tempero, biscoito e picolé (sorvete). Os pregões vocais, instrumentais (no caso do amolador de tesouras e vendedor de taboca) ou mecânicos (com megafone, no caso do carro de frutas ou outros ${ }^{46}$ ) são elemento marcante que compõe o cenário acústico (e olfativo) dos bairros populares, além das sonoras chamadas "Ô, de casa!" nas portas sem campainhas.

Muitas vezes os pregões estão sendo imitados com perfeição pelas crianças que diferenciam as diversas sonoridades que os circundam, dialogando com elas do seu jeito, às vezes, também, fazendo paródias de músicas da moda com letras novas para dar indiretas ou fazer gozação com seus colegas e amigos. Além disso, as crianças mantêm o hábito de brincar de tudo no espaço disponível nas ruas e nos becos estreitos, mesmo que ele pudesse ser maior: jogam bola, brincam de gude, esconde-esconde e pega-pega ${ }^{47}$, explorando o espaço do jeito que está à sua disposição, com um domínio corporal muito desenvolvido. Também há adaptações de brincadeiras: polícia e ladrão ganhou uma versão atualizada, traficante versus polícia, imitando os programas televisivos apelativos. As brincadeiras continuam seguindo ciclos vinculados à natureza: estações mais e menos chuvosas e com mais ou menos vento para poder empinar arraia (pipa). Já os carrinhos de rolimã, ainda em moda uns 15 anos atrás, foram substituídos por pranchas de skate, nos quais os menores descem sentados ou deitados ladeiras abaixo, quando o asfalto ou cimento, muitas vezes em precárias condições, o permite. Especialmente os meninos ganham muito cedo autonomia para o deslocamento nas ruas (mais do que as meninas), visando uma integração no mercado de trabalho informal. Além disso, muitos, a partir de 10 ou 11 anos, já possuem um telefone celular de última geração. Ele vira a ferramenta principal na construção/ no compartilhamento das preferências musicais dos adolescentes. 


\section{Temas transversais em discussão: pertencimento, eficácia, violência e espaço}

Um dos aspectos analíticos principais é a noção de pertencimento que perpassa muitas das situações já apresentadas a serem detalhadas aqui. Trata-se de um conceito que vai do âmbito pessoal ao coletivo e, certamente, tem muito a ver com as múltiplas relações das pessoas com suas participações no espaço público. De encontros familiares na porta de casa, conversas de jovens na esquina a shows com muito público no meio das praças, atraindo também pessoas de ouros bairros, há um constante processo de elaboração de identidade e alteridade, perceptível em falas, gírias, gestos, comportamentos, ações e mesmo em letras de músicas.

O sentimento de pertencimento também fica perceptível, mesmo não verbalizado, de forma mais sutil em situações limite que são mais frequentes do que se imagina: em dias em que falta luz, no início da noite, todos vão para rua para se juntar aos vizinhos, tendo uma vela em casa ou não. Em tempos mais recentes também é possível ver alguém com o celular iluminando o caminho à porta de casa enquanto conversa na espera do retorno da luz, o que pode levar um tempo de minutos a horas e, quando finalmente acontece, é aclamado por todos com palmas e em altas vozes.

No entanto, também há discursos de pertencimento específicos, contestando os estigmas em relação aos bairros populares através de elementos discursivos de autoafirmação, adotados por cantores de pagode, talvez influenciados pelas letras do funk e de congêneres musicais americanos que se baseiam no discurso do gueto. Em várias letras eles nomeiam lugares invisibilizados, tidos como periféricos, falando do cotidiano, levantando assim a "voz do gueto", embora as letras que expressam uma postura de crítica social representem a menor parte do repertório, em geral, composto por músicas de duplo sentido, diferente da cultura do rap. A representatividade que esses músicos e grupos têm transforma-os em exemplo para crianças e jovens que percebem a música local como um possível caminho de futura atuação profissional; por coincidência (ou não), no meu bairro há vários músicos que fazem parte de bandas de pagode com projeção e circulação nacional ${ }^{48}$.
A partir de minha vivência em bairros populares, percebo que o hip-hop, com seu discurso de afirmação política, está menos presente em Salvador do que em cidades do sudeste, em especial São Paulo. Há alguns bairros com a presença de "posses", mas em muitos outros continuam predominando outros estilos musicais, sem claras explicações para isso. O fato de estar em situação de desigualdade social não transforma as pessoas automaticamente em sujeitos conscientes de seus direitos, ávidos por lutar contra injustiças sociais, preferindo estilos musicais voltados para denunciar situações de desigualdade. Tampouco há simplesmente uma sujeição às propostas musicais midiáticas, apenas absorvendo-as, como muitas vezes se ouve falar. Ao contrário, há um processo de constantes trocas e releituras de estilos anteriores e concomitantes, que fazem dos bairros populares usinas criativas de novas propostas musicais como afirmam os tantos grupos que deles surgem.

A noção de pertencimento permeia também a esfera da execução musical. Quem toca não se preocupa tanto com uma possível exigência de perfeição ou excelência técnica, mas muito mais com a capacidade em acolher e proporcionar prazer e pertencimento, isso significa: se o objetivo é dançar, deve ser possível dançar, mesmo que o cantor do conjunto talvez cante fora do padrão "oficial" de afinação. Se a intenção é proporcionar o maior número de participações ativas de pessoas para tocarem e cantarem em uma roda de amigos, vale em primeiro lugar a sua efetiva participação, sem julgamento de qualidade de execução ou busca por competição. Assim, a eficácia de uma atuação musical não se mede necessariamente pela excelência técnica, mas por valores de integração social e trocas entre pessoas, diferente de outros contextos musicais nos quais se busca, talvez, acima de tudo, a excelência técnica que significa perfeição, eficácia e reconhecimento. A partir dessa outra noção de eficácia, as pessoas ganham capacidade de interagir e tocar em público, que se aperfeiçoa no processo da atuação ${ }^{49}$. O que conta é o carisma e a espontaneidade no atendimento às situações do dia-a-dia, tornando a experiência = apresentação um diálogo que busca a capacidade de interação com o público, incluindo até elementos lúdicos ${ }^{50}$. 0 mesmo se percebe também no contexto das tantas igrejas evangélicas de todos os tamanhos e 
vertentes com suas atuações e produções musicais, incentivando a participação musical acima de tudo, independente da excelência técnica já adquirida.

É claro que, mesmo assim, busca-se excelência de forma mais ampla, englobando um conjunto de qualidades que vão da expressão corporal à capacidade de comunicação e carisma, entre outros, incluindo, também, a questão da representatividade como expressão de pertencimento social. Isso significa que entre as tantas bandas de pagode, samba, funk, arrocha, rap ou gospel que se originam nos bairros populares, com uma dose de sorte e relacionamentos, algumas saem do contexto do bairro. Elas vão circular por outros bairros parecidos (conforme suas redes de sociabilidade), tocar em espaços pagos, eventualmente receber apoio financeiro ou moral de alguém (inclusive de um vereador ou de outra pessoa em posição de destaque, até de alguém do poder "paralelo" do tráfico), gravar e postar vídeos no Youtube, serem "descobertas" pela mídia e assim ganhar visibilidade maior. Mas parte importante dessa trajetória é o papel de representatividade que os integrantes desses grupos têm nas suas comunidades, evocando sentimentos de pertencimento de todos os envolvidos na complexa relação de criação, elaboração, apresentação, representação e fruição. Por isso, os casos de grupos bem sucedidos servem de exemplos para crianças e adolescentes na construção de seus referenciais musicais tão presentes no cotidiano. Um caso emblemático é Carlinhos Brown, cuja carreira desenvolveu-se paralelamente a sua participação em atividades no seu bairro de origem, o Candeal de Brotas. O início de sua trajetória coincide com o auge do sucesso do estilo musical anterior ao pagode: o dos blocos afros, grupos percussivos como llê Aiyê e Olodum, e o samba-reggae ${ }^{51}$.

Como ocorreu no Candeal com a Timbalada e a Escola Pracatum de Brown, muitos moradores de bairros populares hoje também participam de ações desenvolvidas por iniciativas culturais/ educacionais do terceiro setor: são grupos e instituições culturais e ONGs, algumas delas atuando como Pontos de Cultura, outras trilhando por caminhos confessionais, algumas são recentes e outras bem mais antigas do que as políticas culturais implantadas no novo milênio. As linguagens abordadas por essas instituições são as mais diversas, dirigindo-se a públicos diferentes nas faixas etárias entre crianças e idosos, bem como os discursos adotados por estas instituições para justificar seu trabalho e sua presença. Elas tanto surgem a partir de iniciativas dos participantes e representam-nos, quanto "vêm de fora", adotam discursos salvacionistas a partir da ideia de oferecer finalmente tudo que supostamente faltava nos bairros, mas, em geral, sem conhecer a realidade local ${ }^{52}$. O total de conjuntos e iniciativas musicais nos bairros é muito maior e mais expressivo do que o número de professores de artes nas escolas públicas. Por exemplo, nas 5 escolas municipais e 5 estaduais na região ampliada do meu bairro há apenas uma professora de música (que já estava lá bem antes da lei 11.769) e uma de artes plásticas. Isso significa que expressões de música e artes que, de várias formas já fazem parte do cotidiano das pessoas e das ações das instituições do terceiro setor, não estão presentes nas instituições de ensino regular ${ }^{53}$.

A noção de pertencimento também perpassa a questão de violência, mesmo que não exista, aparentemente, nada diretamente comparável aos bailes funks cariocas com suas várias modalidades como "baile de comunidade", "baile de corredor" e "baile normal" no território dos "bondes" (ver CECHETTO, 2006, p. 145-150). Há, porém, algo parecido acontecendo no âmbito do samba e pagode no que diz respeito à existência de grupos que frequentam certos lugares e representam outros grupos que tradicionalmente se estranham e se hostilizam. A violência que leva os "bondes" cariocas a se digladiarem durante os bailes, em territórios baianos pode acontecer tanto em apresentações de grupos musicais locais, quanto até no cotidiano, envolvendo adolescentes que representam bairros diferentes em atos de violência, sendo realizados conforme um ethos próprio, mesmo que muitas vezes passando do limite do bom senso e até do das leis.

Dessa forma, a noção de violência opera em vários níveis: da construção de fronteiras internas entre bairros e/ou facções até as percepções mais difusas, expressas nos estigmas, reforçados pela mídia. Mas qual seria a percepção de insegurança e violência dos próprios moradores: seria uma percepção baseada em vivências com furtos, assaltos e homicídios, amparadas nas estatísticas 
oficiais de criminalidade? Ou ela surge a partir da mídia e dos programas sensacionalistas que geram uma impressão de estar no centro das atenções, não importando o motivo, mas gerando "visibilidade" na TV, mostrando o universo cotidiano das pessoas em tempo real com ar de suspense de um filme de ação? É importante ressaltar que, apesar da violência ser um tema presente em muitos bairros populares, ela não é igual ou constante em todos locais: em geral, os moradores dos bairros populares se sentem seguros nos seus bairros. Existe um contínuo de configurações desses bairros, que vai do provisório ao definitivo, do antigo ao recente, do atendido por serviços públicos ao não atendido, do geograficamente central ao não central, do acessível ao não acessível, do menor ao maior, do temporariamente mais violento ao menos, do organizado em/ representado por associações aos não representados, daquele com espaço verde/ público disponível e o outro sem, com mais expressões culturais ou com menos. Da mesma forma, a violência associada ao e decorrente do tráfico, não acontece de forma linear, mas em ciclos ou ondas, difíceis de serem previstas, dependendo de vários fatores externos. Portanto, o fator violência associado aos bairros populares precisa ser visto com cautela para não generalizar o que não pode/ deve ser generalizado. Sem conhecer essa complexa rede de relações, é impossível pensar em políticas públicas adequadas, pois muitas vezes se pensa apenas em lugares ou então somente em pessoas, sem levar em consideração que se trata de pessoas vivendo em contextos sociais específicos. Assim, percebese que comunidades são organismos vivos que podem adoecer, revigorar, se fortalecer, impor e reinventar, depende de quem nelas mora em determinado período e com quem elas dialogam.

Porém, existe outra violência além dessa mais aparente e comentada pelas mídias, causada pelo tráfico de drogas que se instalou, há poucos anos, atingindo em especial crianças e adolescentes negros de sexo masculino. É a violência resultante da baixa escolaridade, da crônica falta de perspectiva e do alto consumo de álcool: existem muitos pontos nos bairros nos quais homens de idade mediana passam sentados na calçada, bebendo, o dia inteiro. É claro que essas duas faces de violência se retroalimentam e são resultado da mesma causa: o efeito devastador da falta de incentivo e oportunidades de formação e da política de criminalização das drogas que tem sido analisada de forma muito crítica pelo neurocientista americano Carl Hart (2014). A sua análise contundente evidencia muitos paralelos com a situação no Brasil.

Embora o espaço público represente um lugar central na recente discussão da configuração da sociedade brasileira, nos bairros populares ele ganha uma conotação diferente de bairros de classe média ou média alta, pelo fato de ser, muitas vezes, bastante reduzido, apesar de ser utilizado muito mais, talvez por existir uma maior proximidade entre as pessoas. Considero que um dos melhores medidores da saúde de um bairro (popular) e do seu espaço público, entendido como ambiente social, certamente é o fato de ser compartilhado espontaneamente por pessoas como sendo um lugar agradável e atrativo. Portanto, ao vermos crianças brincando em bairros populares, podemos entender isso como sinal de sua integridade, mesmo sabendo que há ainda outro motivo nada desprezível: em muitas casas há pouco espaço para elas brincarem. Por essa razão, a rua torna-se o principal local de integração e socialização, muitas vezes apenas "na porta" da referida casa, podendo se aferir aos poucos mais autonomia à criança nos seus deslocamentos, na medida em que ela se insere no mundo externo da casa, também conforme as características específicas da região ou do bairro. Já para outros, especialmente, os meninos, a rua significa independência e liberdade, pois lá constroem todas as suas referências, positivas e negativas. 0 uso desse espaço dialoga de forma direta com os conceitos de pertencimento e violência ${ }^{54}$.

Portanto, nos bairros populares a rua, tão estigmatizada pela classe média, percebida apenas como local de passagem, mas não de permanência, possui outra conotação, embora a noção "dominante" de perigo aos poucos também se instale nesses bairros (proporcional à percepção de violência presente ou não). Isso fica perceptível na fala de muitos responsáveis que procuram "ocupar" o tempo "livre" de seus filhos com alguma outra atividade, p.ex. em projetos sociais, para "tirá-los" da rua, vista aos poucos de forma negativa, atendendo inconscientemente 
aos tantos slogans de propagandas oficiais que apregoam p.ex. a escola em tempo integral ${ }^{55}$. Além disso, trata-se de bairros que muitas vezes estão pautados nos deslocamentos a pé, contando com inúmeros atalhos apenas para pedestres, mantendo muitos becos e caminhos sem acesso por carros. Com tudo isso, as pessoas persistem em colocar a cadeira na porta, em ficar debruçadas nas janelas para conversar, mantendo, de certa forma, hábitos de vizinhança de cidades interioranas, também com brincadeiras e festas. Elas transformam os bairros populares em movimentados micro-organismos à parte no tecido urbano das grandes metrópoles nas quais o espaço público está sendo ocupado visualmente, acusticamente e fisicamente. Duarte (2011, p.3) chama isso de "inteligência corporal coletiva (espaço público para pessoas e não para carros)" e "o corpo humano como instrumento de mediação de espaços, assim reinventando a cidade".

\section{Conclusão: bairros populares como desafios e possíveis respostas?}

A possibilidade da reinvenção da cidade com seus hábitos e gostos a partir de outro ângulo é um dos aspectos mais importantes da reflexão sobre as possíveis contribuições que os bairros populares podem dar à sociedade brasileira. A necessidade da constante adaptação talvez tenha deixado os seus moradores na condição de maior flexibilidade, funcionando a partir de outros parâmetros em relação ao espaço (coletivo), relações pessoais (vizinhança), compartilhamento e criatividade. Mesmo assim, é difícil determinar qual a relação tênue entre a percepção de possibilidades, o limite do suportável, a vontade de mudança, junção de forças com outras pessoas, levando a criação de coletivos artísticos ou associações: (in)felizmente não há receitas ${ }^{56}$. Por que pessoas se mobilizam em prol de objetivos em comum, buscando melhorias: será que é simplesmente a urgência de problemas que ultrapassam o nível do aceitável e tolerável, atendendo assim a velha máxima que somente a necessidade provoca ações no ser humano? Por tudo isso, parece importante a sociedade brasileira abrir-se para o universo desses bairros, buscando conhecê-los, mas não através de visitas eventuais, como acontece por parte de muitos políticos, e tampouco como turista em busca de aventuras, mas como cidadão aberto a conhecer modos de coletividade, criatividade e superação que brotam nesses espaços, além dos assuntos pelos quais em geral são conhecidos.

Acredito ter mostrado que o conhecimento melhor do modus vivendi de bairros populares e outros espaços urbanos similares, ainda pouco conhecidos por aqueles que definem os caminhos políticos, a formação da opinião pública e de cidadãos, só pode beneficiar a tomada de decisões em muitas esferas da política, incluindo educação e cultura. Tanto a força dos diversos movimentos culturais, quanto das ações educativas de ONGs e suas relações com as escolas, permitem reflexões profundas e levam a novos conhecimentos, mesmo quando oriundos desses contextos urbanos ainda pouco aceitos. As vivências musicais e artísticas são muito mais amplas do que o olhar desatento e preconcebido de fora o imagina, alimentadas pelas complexas redes de sociabilidade, evidenciando o potencial criativo desses bairros, em geral, subestimado, cabendo à música/ às artes o importante papel de ser um catalisador social. Assim, só resta ressaltar as estratégias de adaptação constante e da capacidade de reinventar-se, sempre em movimento.

\section{Postcriptum}

Ao começar o texto no final de 2013, jamais imaginei que iria terminá-lo em um momento tão complexo quanto o Brasil está vivendo em 2015. Volto a me perguntar o que minhas reflexões sobre bairros populares podem trazer para a discussão geral desse cenário: em livre inspiração na argumentação da urbanista Raquel Rolnik em relação à crise hídrica de São Paulo57, arrisco dizer que é a relação perturbadora entre realidade, possibilidade, catástrofe e utopia e seus possíveis desdobramentos. Para poder trabalhar com educação e cultura é necessário sair da zona de conforto e aceitar os desafios que a multiplicidade dos modos de vida da sociedade brasileira nos oferece. Isso significa incluir a reflexão sobre os lugares nas quais essa vida cultural acontece, também nos bairros populares, favelas e congêneres. Só assim será possível achar inspirações para solucionar os atuais problemas que atingem toda a sociedade brasileira, sem distinção, apesar das diferenças existentes entre classes sociais e locais de moradia ${ }^{58}$. 


\section{NOTAS}

1. Música cantada por Elis Regina nos anos 70.

2. O filme "Cidade de Deus" (2002) foi precedido pelos filmes "5 vezes favela" (1962) e "Orfeu negro" (1959), o último baseado na peça "Orfeu da Conceição", de Vinícius de Moraes (ver Santos (2011)). Posteriormente surgiu o livro "Elite da tropa" (SOARES; PIMENTEL; BATISTA, 2006) que gerou o filme "Tropa de elite" (2007).

3. Ver o livro de Mike Davis "Planeta Favela" (2006) com sua análise nada animadora, além de dados do IPEA: http://bit.ly/1MOtHw5

4. Comecei a escrever esse texto no final de 2013 , a partir de observações etnográficas de muitos anos. Só depois disso descobri, aos poucos, textos recentes que possibilitaram o diálogo com a bibliografia. Cito entre os autores Zaluar \& Alvito (2006), Cunha \& Feltran (2013), Coutinho (2012) e Gonçalves (2013) por fundamentaram e completarem as minhas reflexões.

5. Foram várias pesquisas de iniciação científica e como bolsista CNPq, abordando questões como gostos musicais de jovens, percepções de som e poluição sonora, relações entre projetos do terceiro setor e escolas públicas, emergências religiosas evangélicas, memórias de tradições musicais (LÜHNING, 2010 e 2013)

6. Em várias capas de livros sobre o tema há predominância de uma imagem "típica" da favela: em ângulo de baixo para cima, fotogenicamente "subindo o morro", sempre olhando de fora, com inúmeras casas sobrepostas entre as quais não se percebe nada a não ser alguma árvore solitária. Os moradores nunca aparecem no meio desse mundo (infinito) de casas e ainda menos suas próprias percepções "de dentro", que poderiam evidenciar outros ângulos ou espaços. Seria a imposição de editores ou a expressão acrítica do estereótipo de representação visual, profundamente enraizado na sociedade brasileira que criou (in?) conscientemente a imagem única "da favela", pautada nos morros cariocas?

7. Na eleição para prefeito em Salvador, em 2012, vencida pelo candidato do DEM (Democratas), houve um apoio decisivo de eleitores de bairros populares, incluindo também artistas destes locais. Um dos empenhados na campanha foi o cantor de um dos grupos de pagode mais conhecidos de Salvador, com projeção nacional, que é oriundo do bairro aqui em análise.

8. Na Bahia cito publicações de Serpa (2007 a,b) e Brito (2012), Halley (2010) e Almeida (2011) sobre Recife e João Pessoa e o Laboratório de Estudos da cidade em Fortaleza www.cadernosmetropole.net, que conceituam questões como público/privado, relações de vizinhança e o bairro como discurso, mas representam numericamente menos material em comparação com as pesquisas sobre o Rio de Janeiro.

9. Especialmente o livro "Um século de favela" (ZALUAR; ALVITO, 2006) com várias reedições parece ter impulsionado outros estudos.

10. Também deve ser considerado o fenômeno dos sucessos midiáticos de novelas recentes, abordando bairros populares cariocas e paulistas.

11. Há reportagens recentes sobre as descobertas dos morros pelos cariocas, aproveitando a vista e os novos ares, além de um turismo internacional que busca em especial áreas "pacificadas" do Rio, como o projeto do Ministério do Turismo, Rio Top Tour, lançado em 2010, pautado no conceito de turismo de experiência (http://bit.ly/1XAMgqs). Outras trilhas foram criadas por moradores, como em Paraisópolis (SP), intitulada "Paraisópolis das Artes", http://bit.ly/1ISjqGt, para visitar experiências artísticas no bairro.

12. Esse texto se dirige em especial a pesquisadores e profissionais da área de música e educação.

13. Como exemplo de uma análise diferente desse padrão, cito o texto de Oliveira \& Marcier (2006), que discute o tema favela de forma bem ampla a partir das letras de 125 exemplos de música popular.

14. Ressalto aqui o movimento da literatura marginal, conceito criado pelo escritor paulista Ferrez.

15. Só após ter formulada a pergunta, tomei conhecimento da instigante publicação do Observatório de Favelas (RJ), "O que é a favela, afinal?" (BARBOSA, 2009) com uma proposta parecida com a deste texto, embora não aborde questões de cultura, inseridas depois no livro "Solos culturais" (BARBOSA, 2013).

16. Não encontrei nenhuma definição específica do termo na literatura, a não ser uma aproximação conceitual nas pesquisas e publicações de Serpa 
(2007a, p. 20), que aponta a necessidade de entender os bairros populares apenas como diferentes, realçando assim a alteridade, sem cair nas dicotomias comuns como rico/ pobre ou periferia/centro.

17. É importante lembrar que o fenômeno favela não é apenas brasileiro, mas mundial. Há outros termos que se referem a estruturas similares, mas diferentes, já que a diversidade de tipos de moradia tem a ver com estruturas sociais, incluindo aspectos históricos, econômicos, culturais e até climáticas. Milton Santos (2001, p. 132-154) já previa a necessidade de uma maior discussão sobre o tema.

18. Desde o séc. XX coexistem vários termos, a depender de quem os usava, mas ainda inexiste um levantamento sistemático dos termos usados no passado para designar os vários tipos de agrupamentos urbanos. Exceções são Moreira (2012) - com definições do conceito bairro em vários dicionários de língua portuguesa do final do sec. XIX, substituindo o conceito anterior de freguesia -, Teixeira (1988) e Gondim (2009) ambos discutem a amplitude atual dos termos e seus sinônimos.

19. Ver também a pesquisa recente do IPEA que busca reclassificar números estatísticos na comparação dos censos de 2000 e 2010, ressaltando o aumento proporcional da população baiana residente em aglomerados subnormais (fenômeno similar em Recife e Brasília), mesmo que em termos absolutos tenha ocorrido uma redução do número de habitantes desse tipo de moradia (ver http://bit.ly/1IOc1EF)

20. Foi o caso de badalados empreendimentos imobiliários em Salvador com slogans mercadológicos bastante questionáveis.

21. Sobre os aspectos legais do espaço das favelas cariocas, recomendo o trabalho de Gonçalves (2013).

22. Esse número é uma estimativa minha, resultado de minhas vivências e observações.

23. Isso também fica claro na opção metodológica do IBGE: os dados são acompanhados por fotos e mapas que mostram favelas dos morros cariocas e bairros periféricos de várias capitais, como Belém e Recife, todos bem mais antigos do que os 10 anos de existência ou titularidade de terra, colocados como critérios de definição dos aglomerados subnormais. Considero incorreto postular transitoriedade e efemeridade como critérios e incluir nos dados "comprobatórios" dados de bairros sabidamente bem mais antigos. Isso reforça a ideia de que são os bairros em si que incomodam, independentemente do tempo de existência.

24. O tráfico de escravos oficialmente foi proibido em setembro de 1850 pela Lei Eusébio de Queirós, poucos dias antes da Lei de terras, mas mesmo assim continuou de forma ilegal ainda por décadas até às vésperas da abolição. $A$ força de trabalho da população escravizada, a imigração de trabalhadores europeus e a questão da posse de terra são diretamente interligadas (ver CAVALCANTE, 2005, p.1).

25. As diferenças terminológicas entre bairro, comunidade, periferia etc., ainda são pouco discutidas, sendo que o periférico, à margem, pode ser múltiplo (CUNHA; FELTRAN, 2013, p.7; GONDIM, 2009).

26. Ver sobre estilos de construção baseados em materiais e técnicas locais, completados por novos processos criativos atuais, aproveitando resíduos industriais como garrafas (BARRETTO et alii, 2010).

27. Em pesquisa recente sobre a história do meu bairro no Arquivo Público da Bahia tive que recorrer a várias seções temáticas do século XIX para conseguir pistas: documentos do governo da província e da polícia, livros de notas com contratos de compra a venda de terrenos, testamentos e inventários.

28. O estudo realizado por Alvito $(2013$, p. $190-$ 191) também descreve a densa microestrutura em Acari (RJ) com inúmeras áreas e subáreas que carregam histórias, representações e usos anteriores que acabam sendo inseridas nas nomenclaturas referentes aos bairros, muitas vezes inserindo denominações geográficas que servem como marcadores espaciais (ver LÜHNING; SOUSA, 2012).

29. O espaço desocupado leva artistas até a fazer intervenções artísticas, em geral localizadas em áreas mais nobres http://bit.ly/1XpkwKx, pois, é raro existirem locais abandonados em bairros populares.

30. De forma geral, ainda há poucos estudos sobre 
a história de bairros periféricos ou populares. Um dos poucos estudos que aborda relações entre as esferas de trabalho e de moradia em $1900 \mathrm{em}$ Salvador é o de Vasconcelos (2006), Carvalho \& Pereira (2008) e de forma indireta Reis (2008).

31. ascensão social dos moradores de favelas/ bairros populares e congêneres, também foi abordado por Meirelles \& Athayde (2014) e em http://datafavela.com.br/ abordando indicadores socioeconômicos no Rio de janeiro, que se iguala a observada por mim em Salvador. Muitas pessoas nos bairros populares hoje dispõem de TV plasma, computador, internet, ar-condicionado, máquina de lavar e carro.

32. Nessa equação aparecem relações de diferenças sociais explícitas, embora não perceptíveis à primeira vista: há aqueles que são donos de suas casas (mesmo que não sejam donos do terreno no qual a casa foi construída, já que as questões fundiárias são complicadas/ contestadas) e os que alugam uma casa. Em geral, tudo é chamado de casa, mesmo que haja sempre mais miniapartamentos, termo novo nesse contexto, a serem alugados. É comum encontrar pequenos caminhões que carregam os bens de uma família, composto por geladeira, fogão, TV, camas, armário e estante, além de algumas plantas e roupas, ou de ver mudanças serem feitas a pé, de uma rua para a próxima, homens carregando os objetos mais pesados e mulheres e crianças os mais leves, assim constituindo fluxo migratório interno nos bairros.

33. Nunca vi uma mulher com esse comportamento, se existir uma exceção, ela apenas confirma a regra.

34. Trata-se em geral de jovens negros de sexo masculino, com escolaridade defasada, o mesmo público que aponta entre as maiores vítimas no mapa da violência (WAISELFISZ, 2014), além de Feltran (2011).

35. No meu bairro e ao redor dele há várias igrejas e capelas consagradas a estes santos, atraindo fieis de perto e longe. Algumas delas têm mais que 100 anos de existência.

36. Todas essas religiões encontram-se representadas entre os vizinhos da minha rua.

37. Sobre as complexas relações entre religião e mobilização política ver Zaluar (2006, p.224-227)
38. Há diferenças entre os gêneros: grupos de mulheres ficam em casa ou "nas portas", nos mercados, escolas ou a caminho deles, enquanto há rodas de homens em vários lugares desde a manhã, em especial em botecos, embora também seja comum ver grupos mistos nos bares que se encontram espalhados pelo bairro (ver também Alvito (2006, 193-195) com sua descrição as redes de sociabilidade em Acari que são muito parecidas com as que observei no Bairro do Engenho Velho de Brotas).

39. Ver sobre isso resenha acrítica da visita de um quarteto à periferia de São Paulo: http://bit. ly/1Xp4fW1.

40. A grande proximidade entre as pessoas, causada pela densidade populacional, o tamanho das habitações e o número de moradores por unidade habitacional/ metro quadrado por pessoa, também tem consequências para a noção de individualidade/ privacidade e suas relações com o som. Ela tem uma conotação diferente e muitas vezes é difícil mantêla dentro de casas com poucas divisões internas ou espaços exclusivos para essa ou aquela tarefa (em casas menores, a única mesa serve para comer, preparar as refeições e fazer os deveres escolares). Assim todos podem presenciar quase tudo: de momentos mais íntimos a cenas de discussão ou até de agressão, sendo difícil ter segredos.

41. "Na mira" é o nome de um noticiário televisivo na Bahia, bastante popular, que aborda casos de violência nos bairros populares, expondo muitas vezes pessoas de forma questionável, cuja abordagem e linguagem influenciam o linguajar e o imaginário.

42. Mesmo que os programas promovam uma exposição questionável da vida dos bairros, lembrando os "zoológicos humanos" frequentes no séc. XIX na Europa, nos moradores podem até causar a sensação ambígua de estarem sendo percebidos. Isso se deve ao fato de que os mesmos programas denunciam também problemas nos bairros que precisam de soluções imediatas (falta de água, enchentes, acesso, transporte etc.), chamando a atenção das autoridades.

43. Arrocha é um estilo musical surgido há alguns anos na região metropolitana de Salvador (Candeias), sendo Pablo um dos cantores mais conhecidos em escala local e nacional, além 
de Neto LX, mais recente, representando a vertente de arrocha ostentação, criada por ele. Ambos são baianos.

44. Há novas configurações religiosas em terreiros frequentados por jovens de classes populares, diferentes dos terreiros tradicionais, vários deles no meu bairro e adjacências. Parece que nesses espaços religiosos recentes há uma ênfase na entidade Exu, mensageiro, que, por causa dos seus atributos estigmatizados como "diabo", agora transformados em qualidades, ganhou visibilidade atraindo uma nova clientela dificilmente aceita em casas mais tradicionais.

45. Agradeço a indicação do termo ao jornalista Hugo Mansur.

46. Essa modalidade ganhou novos formatos: uma empresa de telecomunicações começou a vender planos de Internet, banda larga de 15,20, 35 mega com WI-FI grátis, por vendedores devidamente identificados com megafone na mão, anunciando a proposta de porta em porta no meu bairro.

47. Recomendo o filme "Tarja branca" (2014) sobre Iudicidade e o ato de brincar, de Cacau Rhoden.

48. Ver as músicas "Firme e forte" (Psirico), "Baculejo" e "Sou favela" (Parangolé), "Dura realidade" (Fantasmão), "Escola de vida" (Blackstyle), "Cyclone", "Principe do Gueto", "Favela" (A Bronkka), todas bastante apreciadas pelos moradores de meu bairro, inclusive crianças e adolescentes, destacando a popularidade do cantor Marcio Vitor, da banda Psirico, e de integrantes das bandas Pagod`art, Parangolé, todos do bairro e de seu entorno.

49. O oposto disso seria o processo de aperfeiçoamento do músico erudito que em geral só sai de seu espaço de estudo quando a peça estiver pronta. Na Europa essa situação é muito mais acentuada do que no Brasil, onde até se pode ver alguém estudando em público, algo raro no contexto europeu.

50. Os conceitos de "participatory and presentational performance" cunhados por Turino (2008, p.23-65) são muito úteis para a reflexão sobre a prática das músicas brasileiras realizadas nos bairros populares que até concebem formas mistas entre o participativo e o apresentado com momentos de interação.
51. O llê Aiyê, primeiro bloco afro, surgiu em 1974, sendo seguido por vários outros blocos que tiveram enorme repercussão, também midiática, em meados dos anos 80, convivendo desde os anos 90 com o movimento dos grupos de samba que se transformaram aos poucos no estilo atual de pagode baiano.

52. Reflexões críticas sobre o trabalho desenvolvido por estas instituições e as relações com a violência ainda são raras (p.ex. ARAUJO, 2006) e aqueles a partir da percepção dos moradores/ participantes ainda mais recentes (ver p.ex. SILVA, 2011).

53. Há outro agravante: enquanto os educadores sociais de ONGs em geral são oriundos dos contextos sociais dos bairros, só uma parte dos professores das escolas públicas é oriunda de ou mora em bairros populares, o que thes dificulta entender o modo de vida de seus alunos, as preferências musicais, formas de lazer e habilidades, bem como os medos, problemas e sonhos (LÜHNING; CANDUSSO, 2014).

54. Mas, apesar da importância do espaço público como lócus indispensável para o funcionamento desses bairros, a sua importância nem sempre está sendo valorizado pelos próprios moradores: pois se fosse, ele seria mais cuidado em relação ao verde cada vez mais escasso nesses bairros. Como em outros locais é difícil encontrar responsabilidade do indivíduo para com o público, talvez proveniente da pouca presença da esfera pública em muitos bairros populares. Assim, a importância de bens públicos (espaço/ rua/ árvore/ sombra/água), em geral, só é percebida quando envolve também a interesses particulares explícitos ou quando chega a situações limite como atualmente em São Paulo.

55. Apesar disso, o modelo de privatização do espaço e de hábitos já está sendo adotado cada vez mais nos bairros populares. Se antes o tradicional caruru, feito como promessa ou agradecimento, estava sendo ofertado a todos que quisessem comer, hoje está sendo transformado sempre mais em uma festa particular para convidados, além das pessoas que se recusam a comê-lo por questões religiosas.

56. No meu bairro há vários coletivos artísticos e grupos culturais, mas curiosamente não há nenhuma associação ativa, apesar de tratar-se de 
um bairro de quase 40.000 habitantes. A recente tentativa de oficializar um conselho comunitária, representando várias entidades, fracassou depois de 3 anos de ações diversas já realizadas (ver Zaluar (2006) sobre a organização da sociedade civil). Por outro lado, no Rio de Janeiro, existem vários grupos representativos muito atuantes como o Observatório de favelas, o Afro-Reggae e a CUFA - Central :nica de Favelas que conta com filiais em vários estados. As experiências destas três instituições foram recentemente analisados por Jevcholevitch (2013) com apoio da UNESCO.

57. ROLNIK, Raquel. São Paulo: catástrofe ou utopia, Folha de São Paulo, Cotidiano, 26/1/2015. http://bit.ly/1TeR5V7

58. Nota final: não poderia deixar de mencionar o livro clássico da ativista urbana americana Jane Jabobs (2011) que, infelizmente, conheci apenas durante o processo de submissão desse ensaio. Suas ideias antecedem (e dialogam com) muitas das minhas análises e preocupações, expostas no decorrer do meu texto. Por isso, sugiro a leitura de seu livro instigante nesse ano, em que ela teria completado 100 anos.

\section{REFERÊNCIAS}

ALMEIDA, Alexandre Paz. Uma análise sobre sociabilidade, cotidiano e vizinhança em um bairro popular de João Pessoa/PB. Ponto Urbe (Revista do Núcleo de Antropologia Urbana da USP), n. 9, 2011. http://pontourbe.revues.org/287

ALVITO, Marcos. Um bicho-de-sete-cabeça". In: ZALUAR, Alba; ALVITO, Marcos (Orgs.). Um século de favela. Rio de Janeiro: Editora FGV, 2006. p. $181-208$.

AMARAL, Paulo Murilo. Estigmaecosmopolitismo de uma música popular urbana de periferia: etnografia da produção do tecnobrega em Belém do Pará. Porto Alegre, UFRGS, 2009. Disponível em: http://bit.ly/1XAGncF

ARAÚJO, Samuel et alli. A violência como conceito na pesquisa musical: reflexões sobre uma experiência dialógica na Maré, Rio de Janeiro. Revista Transcultural de Música/ Transcultural Music Review, no. 10 (2006).

BARBOSA, Jorge Luiz (Org.). o que é a favela, afinal? Rio de Janeiro, Observatório de Favelas, 2009.

; DIAS, Caio Gonçalves. Solos

culturais. Rio de Janeiro, Observatório de Favelas, 2013.

BARRETO, Demis Ian Sbroglia; WEIMER, Günter; MEDEIROS, Humberto; HOLZER, Werther. A arquitetura popular do Brasil. Rio de Janeiro, Bom Texto Editora, 2010.

BAUMAN, Zygmunt. Confiança e medo na cidade. Rio de Janeiro, Editora Zahar, 2009.

BRITO, Marcelo Sousa. o teatro invadindo a cidade. Salvador, EDUFBA, 2012.

BRASIL. Ministério Planejamento, Orçamento e Gestão. Instituto Brasileiro de Geografia e Estatística, IBGE, Censo Demográfico, 2010, Aglomerados subnormais. Primeiros resultados. Rio de Janeiro, 2011a, http://bit.ly/1106Swl, e, em formato mais detalhado em :

Censo Demográfico, 2010,

Aglomerados subnormais. Primeiros resultados. Rio de Janeiro, 2011 b, http://bit.ly/1HUwtMl.

BUENO, Laura Machado de Mello. Nem tudo que é irregular é precário. (Suplemento Sobrecultura, n. 5). Ciência Hoje, agosto 2011, p.3.

Contribuição para o

conhecimento sobre as favelas no Brasil. In: BARBOSA, Jorge Luiz (Org.). 0 que é a favela, afinal? Rio de Janeiro, Observatório de Favelas, 2009, p. $46-51$.

CADERNOS DA CIDADE, Secretaria Municipal de Desenvolvimento Urbano, Habitação e Meio Ambiente - SEDHAM/ COPI, Salvador, Ano I, N. 1, junho de 2009, Volume 1. http://bit.ly/1TflcvN

CAFFÉ, Carolina; HIKIJI, Rose Satiko G. A Arte e a Rua: uma Experiência Colaborativa Audiovisual com Artistas de Cidade Tiradentes. Revista de Cultura e Extensão USP, vol.7, 2012. http://bit. ly/1liwOh3

CARVALHO, Inaiá M. Moreira de; PEREIRA, Gilberto Corso. As "cidades" de Salvador. Salvador: Edufba, 2008. http://bit.ly/10yKq6Z

CAVALCANTE, José Luiz. A Lei de Terras de 1850 e a reafirmação do poder básico do Estado sobre a 
terra. 2005. http://bit.ly/1NjdD6R

CECHETTO, Fatima Regina. Galeras funk cariocas: os bailes e a constituição do ethos guerreiro. In: ZALUAR, Alba; ALVITO, Marcos (Org.). Um século de favela. Rio de Janeiro: Editora FGV, 2006, p. $145-166$.

COUTINHO, Marina Henriques. A favela como palco e personagem. Rio de Janeiro: FAPERJ, 2012.

CUNHA, Neiva Vieira da; FELTRAN, Gabriel de Santis (Orgs.). Sobre periferia: novos conflitos no Brasil contemporâneo. Rio de Janeiro: Lamparina e FAPERJ, 2013.

DAVIS, Mike. Planeta favela. São Paulo: Boitempo, 2006.

DUARTE, Cristóvão Fernandes. A reinvenção da cidade. (Complemento Sobrecultura), n.5, Ciência Hoje, agosto de 2011, p.3.

A "reinvenção" da cidade

a partir dos espaços populares. In: BARBOSA, Jorge Luiz (Org.). o que é a favela, afinal? Rio de Janeiro, Observatório de Favelas, 2009, p. 5961.

FELTRAN, Gabriel de Santis. Fronteiras de tensão: política e violência nas periferias de São Paulo. São Paulo: Editora Unesp, 2011.

GONÇALVES, Rafael Soares. Favelas do Rio de Janeiro: história e direito. Rio de Janeiro: Editora PUC-Rio, 2013.

GONDIM, Linda M.P. Favela, aglomerado subnormal, comunidade, ocupação, assentamento precário - "diga lá, o que é, o que é?" In: BARBOSA, Jorge Luiz (Org.). 0 que é a favela, afinal? Rio de Janeiro, Observatório de Favelas, 2009, p. 54 -58 .

HALLEY, Bruno Maia. De Chapéu do Sol a Água Fria: numa trama de enredos, a construção da identidade de um bairro na cidade do Recife. (Dissertação). Universidade Federal de Pernambuco. Recife, 2010.

HART, Carl. Um preço muito alto: a jornada de um neurocientista que desafia nossa visão sobre as drogas. Rio de Janeiro, Zahar, 2014.

HIKIJI, Rose Satiko G., CAFFÉ, Carolina. Artes da periferia: conflitos em Imagens, música e dança. In: FELTRAN, Gabriel de Sanctis; CUNHA, Neiva Vieira da (Orgs.). Sobre periferias. Novos conflitos no Brasil contemporâneo. Rio de Janeiro: Editora Lamparina/FAPERJ, 2013, p.88 -100.

JACOBS, Jane. Morte e vida das grandes cidades. São Paulo: Martins Fontes, 2011 (2000).

JOVCHELOVITCH, Sandra. Underground sociabilities: identity, culture and resistance in Rio de Janeiro's favelas. Brasília: UNESCO, 2013.

KLEBER, Magali Oliveira. A prática de educação em ONGs: dois estudos de caso no contexto urbano brasileiro. Curitiba: Appris, 2014.

LÜHNING, Angela. Etnomusicología en contextos comunitários. Boletin Musica. Casa de las Américas, v. 27, p. 3-22, 2010.

Na Encruzilhada dos Saberes e Fazeres Musicais: leis, conhecimentos tradicionais, educação, música e espaço(s). In: VIEIRA, Lia Braga; TOURINHO, Cristina; ROBATTO, Lucas. (Orgs.). Trânsito entre fronteiras na música. Belém: PPGArtes/UFPA, 2013, p. 11-54.

PAMFILIO, Ricardo. Os meandros sinuosos entre história oral e documentação fotográfica: capoeira em Salvador nas fotos de Pierre Verger. Musica\& Cultura, v. 7, p. 70-87, 2012.

; CANDUSSO, Flávia. Trocando experiências: relações entre educação musical, etnomusicologia e contextos culturais na percepção de educadores sociais na Bahia. CONGRESSO DA ANPPOM, 24., 2014, São Paulo.

Anais... São Paulo, 2014.

MAGNANI, José Guilherme Cantor. Da periferia ao centro: trajetórias de pesquisa em antropologia urbana. São Paulo: Editora Terceiro Nome, 2012.

MAIA, João; BISPO, Mariana. Os favela tours: uma análise dos relatos dos usuários de um fórum de discussão comparada com a visão dos moradores de uma comunidade visitada no Rio de Janeiro. Periferia: Educação, Cultura \& Comunicação, vol.2/2, 2010, http://bit.ly/1MMYnOb

MEIRELLES, Renato; ATHAYDE, Celso. Um país chamado favela: a maior pesquisa já feita sobre a favela brasileira. São Paulo: Editora Gente, 2014. 
MOREIRA, Luciana Veronica Silva. Apontamentos sobre o uso do bairro enquanto categoria de análise histórica. ENCONTRO REGIONAL DA ANPUH, 18., 2012 Anais. http://bit.ly/1lnXXoa

OLIVEIRA, Jane; MARCIER, Maria Hortense. 'A Palavra é: favela`. In: ZALUAR, Alba; ALVITO, Marcos (Orgs.). Um século de favela. Rio de Janeiro: Editora FGV, 2006, p.61- 114.

SANTOS, Roberto Elísio dos. 2 Vezes 5 Vezes Favela: aproximações e distanciamentos do cinema brasileiro. Intercom, Revista Brasileira Ciências da Comunicação, v.34/2, São Paulo, 2011. http://bit.ly/10oOW9Y

SANTOS, Mário Silva. Crescimento urbano e habitação em Salvador (1890-1940). Rua (Revista do Mestrado em Arquitetura e Urbanismo), Salvador, v. 3, 1990, p. 20- 29. http://bit.ly/1Nk6zXG

SANTOS, Milton. Por uma outra globalização: do pensamento único à consciência universal. Rio de Janeiro: Editora Record, 2001.

SERPA, Angelo (Org.). Espaço público na cidade contemporânea. Salvador, EDUFBA/ São Paulo, Editora Contexto, 2007a.

Cidade popular: trama de relações sócio-espaciais. Salvador, EDUFBA, 2007b.

SILVA, Alexandre Dias da. Música e projetos sociais na favela da maré: reflexões para estudo de caso sobre a prática musical das ONGs que atuam na Maré. ENCONTRO NACIONAL DA ASSOCIAÇÃO BRASILEIRA DE ETNOMUSICOLOGIA, 5., 2011, Belém. p.29- 38. http://www.cult.ufba.br/ wordpress/24636.pdf

SOARES, Luiz Eduardo; PIMENTEL, Rodrigo; BATISTA, André. A elite da tropa. São Paulo: Objetiva, 2006.

SOUZA, Marcelo José Lopes de. O bairro contemporâneo: ensaio de abordagem política. Revista Brasileira de Geografia. (Rio de Janeiro), vol.51, n.2, p.140 -172, 1989. http:// bit.ly/1YC9nTT

TEIXEIRA, Marlene P.V, MACHADO, Rosa, Maria. Conceito de bairro - unidade popular ou técnica. In: Anuário do Instituto de Geociências da
UFRJ, 1986, p.66 -71. http://bit.ly/1SqQHms

TURINO, Thomas. Music as Social Life. The politics of participation. Chicago: The University of Chicago Press, 2008.

VASCONCELOS, Pedro de Almeida. Pobreza urbana e a formação de bairros populares em Salvador na longa duração. GEOUSP - Espaço e Tempo, São Paulo, n. 20, p. 19 - 30, 2006. http://bit.ly/100059i

WAISELFISZ, Julio Jacobo. Mapa da violência os jovens do Brasil. Rio de Janeiro: FLACSO Brasil, 2014. http://bit.ly/1IUAF6M

ZALUAR, Alba. Crime, medo, política. In: ZALUAR, Alba; ALVITO, Marcos (Orgs.). Um século de favela. Rio de Janeiro: Editora FGV, 2006. p.209232.

; ALVITO, Marcos (Orgs.). Um século de favela. Rio de Janeiro, Editora FGV, 2006.

\section{SITES E NOTÍCIAS JORNALÍSTICAS}

Conceito de moradia popular reforça segregação, Carta Capital, 22/10/2013, http://bit. ly/1ItdTed

'Gaudí Brasileiro': Arte e arquitetura na favela, Yahoo Notícias, 23/1/2015, http://bit. ly/1TIZLtw

Como anda Salvador, Observatório das metrópoles, UFRJ, (sem data), http://bit. ly/10yJJuA

Rio Top Tour estimula inclusão social pelo turismo: Portal Brasil, Ministério do Turismo, 30/8/2010, http://www.brasil.gov.br/turismo/2010/08/ rio-top-tour-estimula-inclusao-pelo-turismo-1, http://bit.ly/10ylcG5

Bárbara Nascimento, professora e ativista: 'A lotação do Vidigal está esgotada', O Globo, Sociedade, 6/1/2015, http://glo.bo/1PloxLS

Concerto muda noite na periferia de São Paulo, Folha de São Paulo, Ilustrada, 28/3/2013, http://bit.ly/1Xp4fW1

Record grava novela "Vias opostas" em favela no Rio, Folha de São Paulo, llustrada, 18/9/2006, http://bit.ly/1PIX9gM 
Elenco de "I Love Paraisópolis" começa a gravar em favela em São Paulo, UOL Notícias, 2/11/ 2015, http://bit.ly/1livVoF

Mostra no Rio ocupa lugares abandonados com instalações, Folha de São Paulo, llustrada, 20/01/2015, http://bit.ly/1XpkwKx

\section{SOBRE A AUTORA}

Angela Lühning (PhD em Vergleichende Musikwissenschaft/ etnomusicologia, Freie Universität Berlin, 1989) é professora de etnomusicologia da Escola de Música da Universidade Federal da Bahia. Trabalha com culturas afro-brasileiras e indígenas, sobre assuntos que abrangem de gravações históricas, epistemologias e relações de poder, formação de educadores musicais a práticas musicais populares em comunidades afro-brasileiras contemporâneas e suas dimensões históricas. Também atua há anos na Fundação Pierre Verger (Salvador) e publicou livros, artigos e outros materiais sobre estes vários temas. 